\title{
Attitude of Saudi Female Math Teachers toward Integrating E- learning in Teaching Math at High Schools in Saudi Arabia
}

Aishah M. Albalawi

Follow this and additional works at: https://researchrepository.wvu.edu/etd

\section{Recommended Citation}

Albalawi, Aishah M., "Attitude of Saudi Female Math Teachers toward Integrating E-learning in Teaching Math at High Schools in Saudi Arabia" (2013). Graduate Theses, Dissertations, and Problem Reports. 7298.

https://researchrepository.wvu.edu/etd/7298

This Dissertation is protected by copyright and/or related rights. It has been brought to you by the The Research Repository @ WVU with permission from the rights-holder(s). You are free to use this Dissertation in any way that is permitted by the copyright and related rights legislation that applies to your use. For other uses you must obtain permission from the rights-holder(s) directly, unless additional rights are indicated by a Creative Commons license in the record and/ or on the work itself. This Dissertation has been accepted for inclusion in WVU Graduate Theses, Dissertations, and Problem Reports collection by an authorized administrator of The Research Repository @ WVU.

For more information, please contact researchrepository@mail.wvu.edu. 
Attitude of Saudi Female Math Teachers toward Integrating E-learning in Teaching Math at High Schools in Saudi Arabia

\author{
Aishah M. Albalawi \\ Dissertation submitted to the \\ College of Education and Human Services \\ at West Virginia University \\ in partial fulfillment of the requirements \\ for the degree of \\ Doctor of Education \\ in \\ Curriculum and Instruction \\ Joy F. Saab, Ed.D., Chair \\ Steven D. Rinehart, Ed.D. \\ Ernest R. Goeres, Ph.D. \\ Patricia Obenauf, Ed.D. \\ Perry D. Phillips, Ed.D.
}

Department of Curriculum and Instruction/Literacy Studies

Morgantown, West Virginia

2013

Keywords: Teachers' Attitudes; Adopting Technology; E-learning; Saudi Arabia

Copyright 2013 Aishah M. Albalawi 
All rights reserved

INFORMATION TO ALL USERS

The quality of this reproduction is dependent upon the quality of the copy submitted.

In the unlikely event that the author did not send a complete manuscript and there are missing pages, these will be noted. Also, if material had to be removed, a note will indicate the deletion.

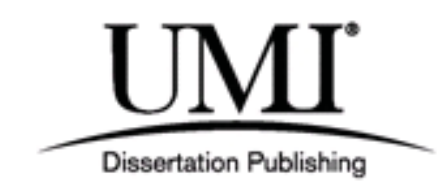

UMI 3605767

Published by ProQuest LLC (2013). Copyright in the Dissertation held by the Author.

Microform Edition (C) ProQuest LLC.

All rights reserved. This work is protected against unauthorized copying under Title 17, United States Code

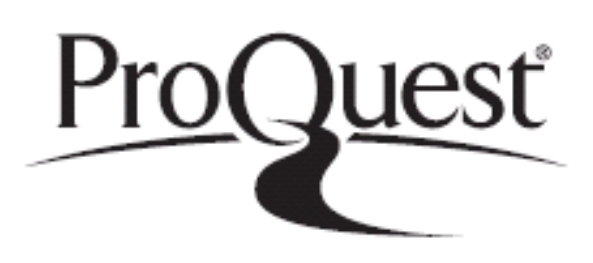

ProQuest LLC.

789 East Eisenhower Parkway

P.O. Box 1346

Ann Arbor, MI 48106 - 1346 


\title{
ABSTRACT \\ Attitude of Saudi Female Math Teachers toward Integrating E-learning in \\ Teaching Math at High Schools in Saudi Arabia
}

\begin{abstract}
Aishah M. Albalawi
Leaders in government and education have launched an extensive program to reform general education in Saudi Arabia. This initiative was designed to achieve many goals with a major emphasis being the enhancement of the Saudi curriculum to take advantage of the use of technology to improve education. A goal of this project was for e-learning to be a part of public education in an attempt to improve student learning and to make education accessible to all citizens.
\end{abstract}

This study was designed to examine high school female math teachers' attitudes toward the use of e-learning in teaching mathematics in selected high schools in Tabuk, Saudi Arabia. It also sought to determine the extent to which e-learning had been adopted in high schools. The study also examined the results to determine if there were any statistically significant differences in female math teachers' attitudes toward e-learning based on the variables of academic degree, years of experience, computer course training, and computer lab availability.

A 5-point Likert scale questionnaire was used to collect data on teacher attitudes toward the use of e-learning in education. Descriptive statistics were used to analyze much of the data generated from the questionnaire. Means, standard deviations, ranges, frequencies, percentages, and diagrams were used to compile and analyze the data. A $t$-test was used to test for statistically significant differences in teachers' attitudes for the variables of academic degree, years of experience, computer course training, and computer lab availability.

The analysis of the responses to the questionnaire revealed that the female high school math teachers' attitudes toward the use of e-learning were highly positive. The mean responses to the questionnaire items revealed that the teachers believed that e-learning made teaching more effective, more interesting, and enhanced the quality of teaching. There was general agreement that e-learning helped them meet the individual needs of the learners. The results of the study revealed that there were no statistically significant differences in teachers' attitudes toward elearning when examined for the variables of academic degree, years of teaching experience, computer course training, and computer lab availability. Recommendations were made for professional development, in-service training, technology integration, and logistics and infrastructure improvement. 


\section{DEDICATION}

This dissertation is dedicated to my parents, who were behind me throughout all of my studies--inspiring me, assisting me, and providing me with peace of mind. I am greatly indebted to them for their support and encouragement.

This achievement also is dedicated to my dear husband and lovely children. Special gratitude and honor go to my brothers and sister, who accompanied me on this journey. 


\section{ACKNOWLEDGEMENT}

I would like to thank my former advisor, Dr. Perry Phillips, who has inspired me to move forward and concentrate my efforts toward achieving the goals I had set. I am fortunate to have had him as an advisor as he not only encouraged me to explore the unthinkable but also guided me during times of crisis. His support and patience were instrumental in my completing this dissertation. It is my deepest wish that I will be able to follow his model when I become a leader for students in Saudi Arabia. I wish that one day I will be as good to my students as Dr. Phillips was to his. I learned a lot from him as a person and teacher.

To my faculty, friends, and family members who have helped me complete this dissertation, I am forever in your debt. I will not forget the support of my committee members for their contributions to this dissertation.

Finally, my deepest gratitude goes to all of you who have provided the encouragement, experience, and guidance necessary for me to develop as a doctoral student during my years at West Virginia University. 


\section{TABLE OF CONTENTS}

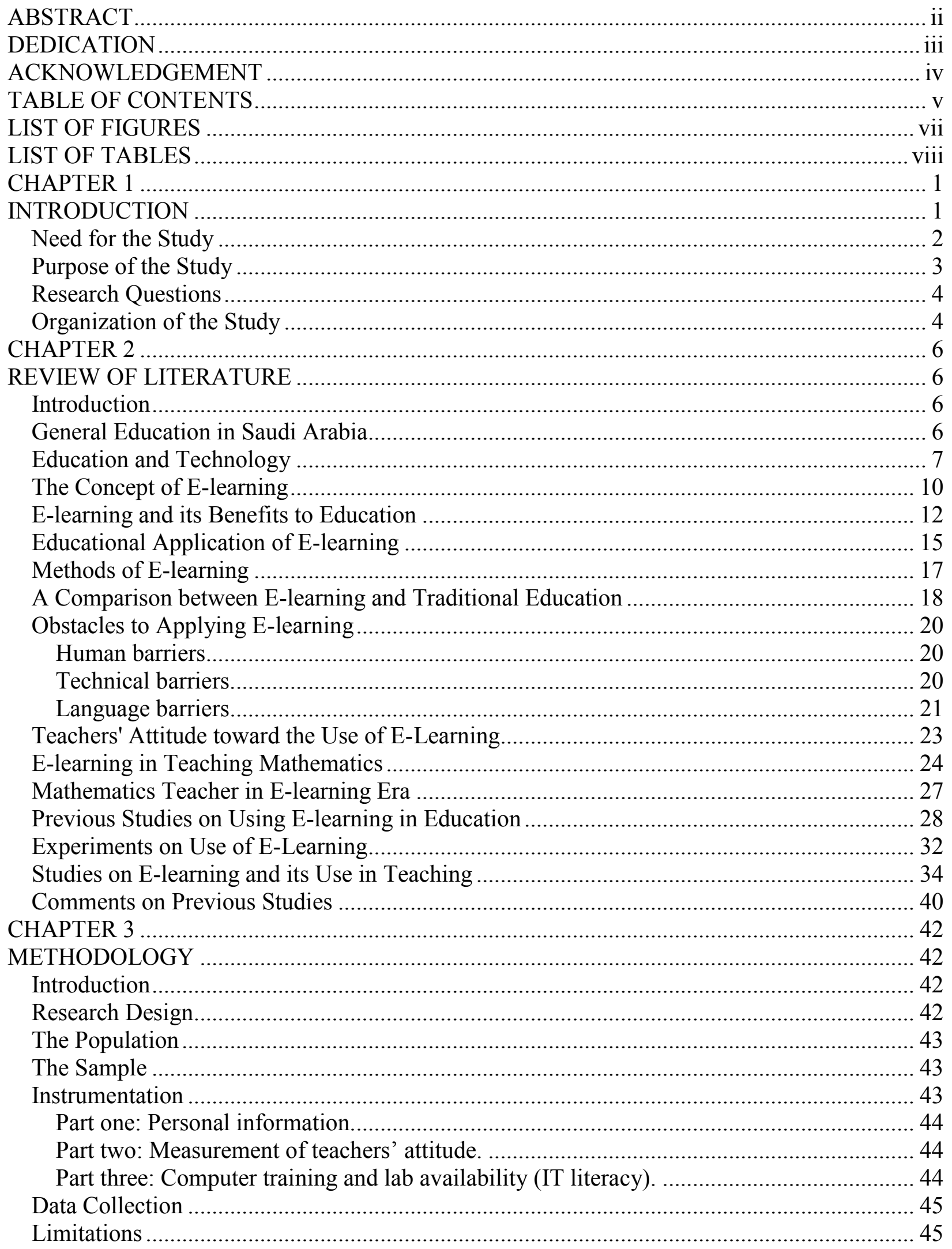




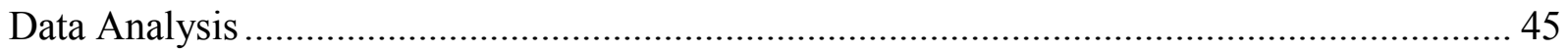

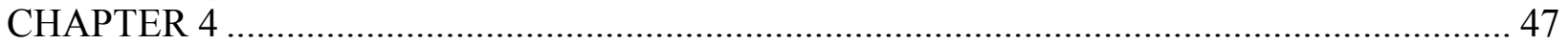

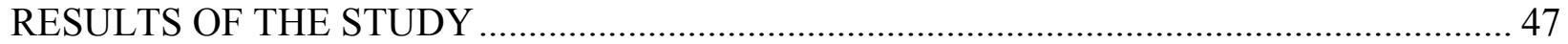

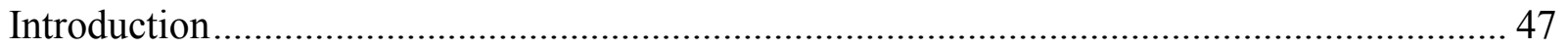

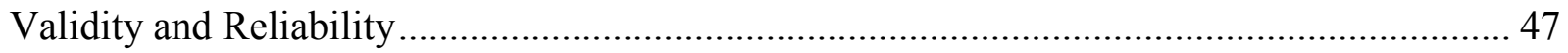

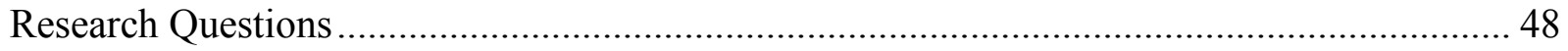

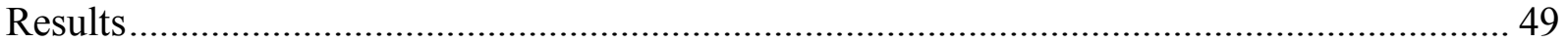

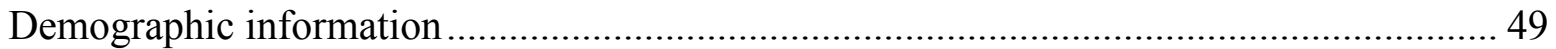

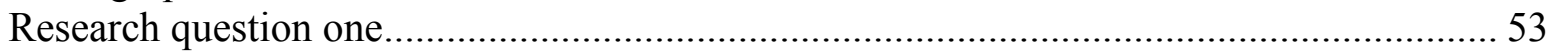

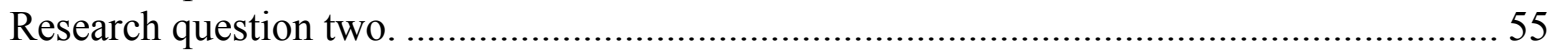

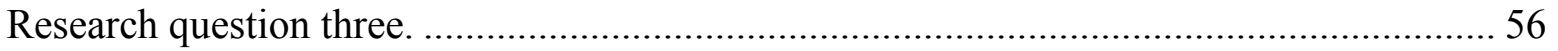

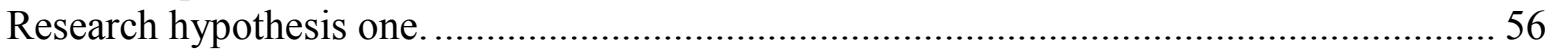

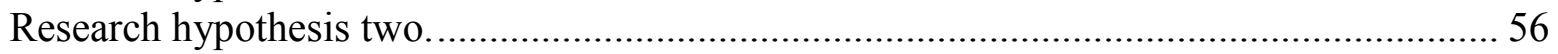

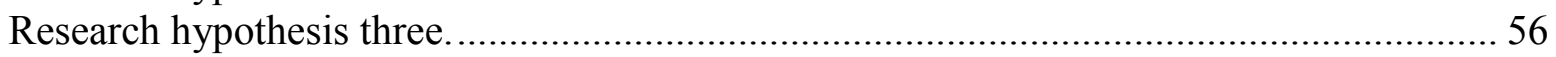

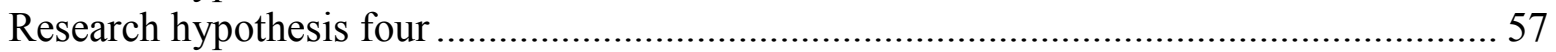

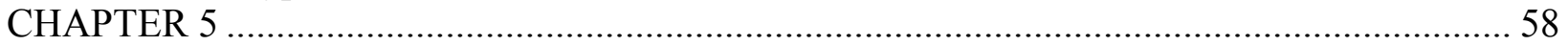

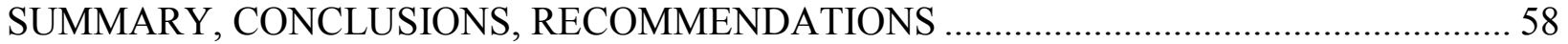

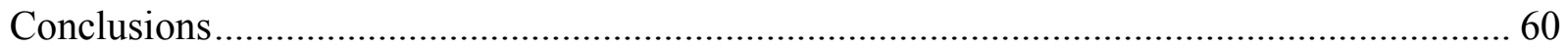

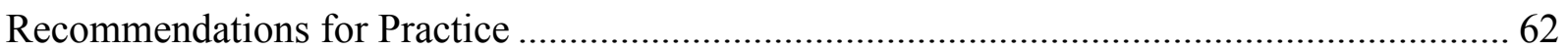

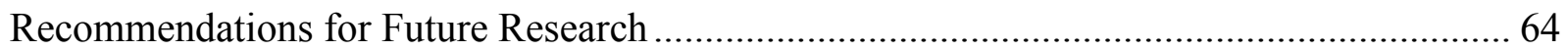

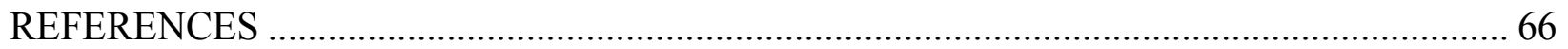

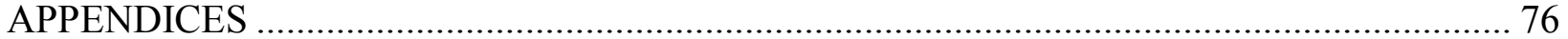

Appendix A English Version of the Survey: A Questionnaire of Female Teachers' Attitudes toward Adopting E-Learning in Teaching Math.................................................................. 77

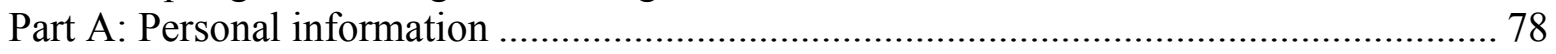

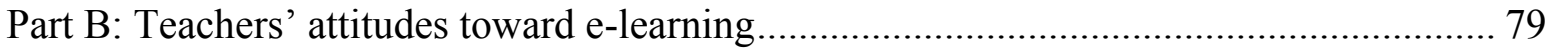

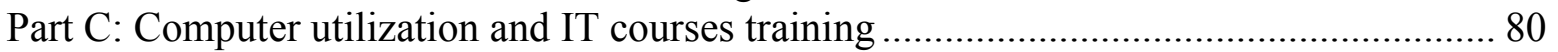

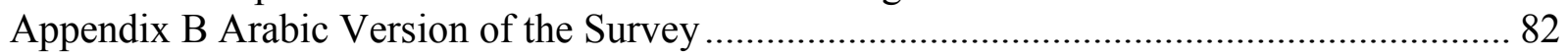

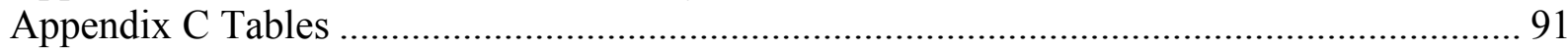




\section{LIST OF FIGURES}

Figure 1. Years of teaching experience for participants................................................ 50

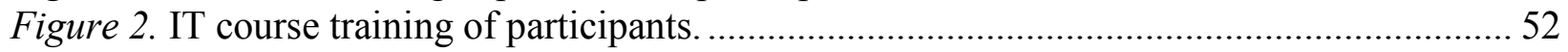

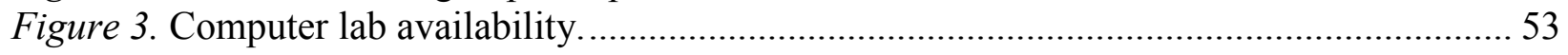




\section{LIST OF TABLES}

Table 1 Comparison between E-learning Approach and Traditional Approach (Saudi Arabia). 19

Table 2 Years of Teaching Experience ..... 50

Table 3 Academic Degree of Participants ............................................................................. 51

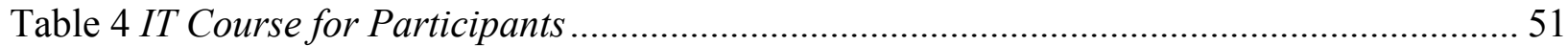

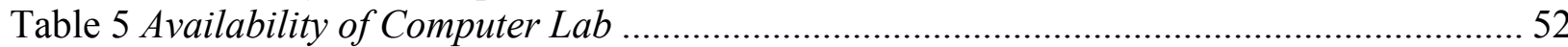

Table 6 Correlation with Lab Availability............................................................................... 57

Table 7 Frequencies Tables of Subjects and Percentages for the Study ................................... 92

Table 8 Means, Standard Deviations, and t-test Values for Academic Degrees ........................ 96

Table 9 Teachers' Response Variance for Years of Teaching Experience ................................. 98

Table 10 Means, Standard Deviation, and t-test Values for Computer Training Courses......... 101 


\section{CHAPTER 1}

\section{INTRODUCTION}

The Kingdom of Saudi Arabia is not only a developing country, but also a country with rich oil resources used to promote and develop its educational system. The Saudi government sees education as an investment in the future and allocates a lot of money toward human development. When the Kingdom was established in 1932, education was not accessible to everyone, but was limited to individualized instruction at religious schools in urban mosques (Alhaamed, Abdulqader, Alotiybi, \& Metulee, 2007). These schools taught Islamic law and basic literacy skills. However, by the end of the century, Saudi Arabia had a nationwide system that provided a free education from preschool through the university that was available to all citizens and residents (Alhaamed et al., 2007). The modern Saudi educational system provides quality instruction in diverse fields of modern and traditional arts and sciences, with religious studies as its core. Being a center of the Islamic world and having the two most important Islamic shrines in Makkah and Madinah, the Kingdom attracts many educated Muslims from all over the world. The population diversity helps meet the Kingdom's growing need for highly educated citizens to help build on its rapid progress. King Fahd bin Abdulaziz (1982-2006) often stressed that the young people of Saudi Arabia are the country's most valuable resource (MoE-SA, 2011).

Formal education began in Saudi Arabia in the 1930s (Alsunbol, Alkhateeb, Metwalli, \& Abduljawad, 2004). By 1945, King Abdulaziz bin Abdulrahman Al-Saud (1899-1952), the country's founder, had initiated an extensive program to establish schools in the Kingdom. Rapid developments in opening new schools resulted in 226 schools with 29,887 students in the country by 1951 (Alsunbol et al., 2004). In 1953, the Ministry of Education was established, headed by Prince Fahd bin Abdulaziz as the first Minister of Education. Riyadh University, the 
first university in the Kingdom (now known as King Saud University), was founded in Riyadh in 1957 (Alsunbol et al., 2004).

Today, Saudi Arabia's nationwide public educational system includes more than 20 public universities, 20 private universities, and hundreds of colleges and other educational and training institutions. Additionally, more than 24,000 schools for boys and girls have been established. The education system provides students with free education, books, and health services (Alaqeel, 2005). Strong evidence of the government's substantial commitment to this sector is its allocation of over $25 \%$ of the annual state budget for education, including vocational training (MoE-SA, 2011).

The present king, King Abdullah bin Abdulaziz, has launched an extensive program to reform general education in Saudi Arabia. A huge budget was set for this project, and a group of consultants with educational expertise were assigned to ensure its success (Alhaamed et al., 2007). This initiative was designed to achieve many goals, chief among them enhancing the Saudi curriculum to cope with technological challenges, developing student's critical thinking and self-learning, and promoting Islamic values and loyalty to country (Alhaamed et al., 2007).

This initiative was started in 2006 and was planned to continue for six years (Alaqeel, 2005). A goal of this project was to pave the road for e-learning to be a part of public education. Schools started to implement the first phase of this project, so computer labs and Internet service became a part of every school. Social and media orientations for e-learning were conducted, and e-learning was integrated in course curricula (MoE-SA, 2011).

\section{Need for the Study}

The objectives of this study were to investigate the status of e-learning adaptation and integration into the teaching of math by female high school mathematics teachers. This study 
was designed to determine the extent to which female high school mathematics teachers incorporated the use of instructional technology in the teaching of mathematics in their classrooms in Saudi Arabia. This study was designed to assist decision makers in Saudi Arabia's Ministry of Education, as well as Saudi administrators and mathematics teachers, in evaluating the importance of using e-learning to teach math.

This study, examining the use of e-learning by female high school mathematics teachers, could provide information to the Ministry of Education that might be useful in addressing the shortage of female math teachers in a country where this shortage cannot be addressed by male teachers employing face-to-face instructional methods. E-learning provides the opportunity for more female math teachers to learn mathematics in an environment where there can be face-toface contact with other female teachers of math. E-learning will enhance the quality of preparation of female teachers of mathematics because direct interaction can occur between teacher and student where questions may be asked and answers received immediately.

The findings of this study are expected to generate recommendations and suggestions for applying the best strategies and practices to assist high school educational institutions for females in Saudi Arabia to adopt and use e-learning in their educational processes more efficiently and effectively. The results and outcomes might suggest that the integration of elearning into education will help to achieve the major "goal of teaching," which is to provide education with technology for the benefit of society in general. Eventually, this study may also provide pathways for future investigators to study e-learning in other disciplines.

\section{Purpose of the Study}

The purpose of the study includes the following points: 
1). To examine the attitudes of high school female math teachers towards using elearning.

2). To find out to what extent e-learning is disseminated and adopted by female math teachers in high schools.

3). To investigate the effects of certain variables such as academic qualification, years of experience, IT training courses, and computer lab availability, on adopting e-learning by female high school math teachers.

Also, this study may reveal other objectives that may arise during the research in relation to obstacles that obstruct or impede e-learning implementation and integration.

\section{Research Questions}

The research questions addressed in this study are as follows:

1). What is the attitude of female mathematics teachers in high school towards using elearning?

2). To what extent does using e-learning in high schools support education?

3). Are there any statistically significant differences among female math teachers' attitudes toward the use of e-learning in teaching math due to the following variables:

a. academic degree,

b. years of experience,

c. computer courses training, and

d. computer lab availability.

\section{Organization of the Study}

This study consists of five chapters in addition to appendices. Chapter 1 provides an introduction to education in Saudi Arabia and a discussion on the integration of technology in 
education. It addresses the need for the study, the purpose of the study, and research questions. In Chapter 2, a review of studies related to Saudi education, e-learning, integration of e-learning in education, and the use of e-learning in teaching mathematics is presented. Chapter 3 presents the methodology used in this research. Chapter 4 presents the results and analyses of the data. It provides a discussion of the study questions and hypotheses. Chapter 5 presents the conclusion and implications of the study. Finally, the researcher ends this study with a summary of recommendations for future research. 


\section{CHAPTER 2}

\section{REVIEW OF LITERATURE}

\section{Introduction}

The quality of education in many countries of the world has come under scrutiny in recent years. The issues of student achievement, teacher proficiency, and curriculum became important topics for research with the hope that factors might be uncovered that would lead to an increase in student achievement and to an increase in satisfaction with the learning process. Research in the area of computer and Internet applications to education seems to suggest that there was potential here for connecting to students and for improving the achievement level of students. There also appeared to be strong interest on the part of teachers and administrators toward using these new technologies to improve teaching and learning. This study is designed to investigate how the application of technology might affect education. Specifically, it is designed to investigate female mathematics teachers' attitudes toward using e-learning to teach mathematics. Studies related to the use of e-learning in education, especially in math, will be discussed in this chapter. This literature review is divided into several topics: concept of elearning, the revolution to e-learning, educational use of e-learning, advantage of e-learning, obstacles in the way of using e-learning, teachers' attitudes toward using e-learning in education, use of e-learning in math, and the new role for mathematics teachers in the e-learning era.

\section{General Education in Saudi Arabia}

Education in Saudi Arabia has characteristics to fit the unique situation of the country. According to the Kingdom of Saudi Arabia Millennium Development Goals Report (2010) by the Ministry of Economy and Planning, the main objectives of the Saudi Arabian educational policy are "to ensure that education becomes more efficient, to meet the religious, economic and 
social needs of the country and to eradicate illiteracy among Saudi adults" (as cited in Al-Shabi, 2013, p. 272). Providing education to all citizens, males and females, anywhere in the Kingdom is considered the main objective.

Due to the nature of the country and according to the Islamic customs and the conservative nature of society, non-related males and females are not to mix in public (Alsunbol et al., 2004). Public education is divided into two separate branches for males and females (Alaqeel, 2005). Both systems purport to offer the same education, the same syllabi, and the same attention. The education plan is 6-3-3: i.e., six years of compulsory elementary education, three years of intermediate education, and three years of secondary school education (Alaqeel, 2005). In addition, there is an optional kindergarten. The Ministry of Education is fully responsible for funding and regulating the educational process for both genders.

In 1970, when King Fahad was the first minister of education, a development occurred that transformed general education. This development formed a new process by which curriculum planning and development was to occur. A new management system was created to design the necessary studies for educational planning and curriculum developments to be in line with the needs of society and with modern developments in education. During King Fahad's era (1982-2005), one of the most prominent developments was the introduction of computer science as a main subject in general education.

\section{Education and Technology}

Changes in teaching methods, the purpose of teaching, and the way we learn have taken place in the last three decades as a result of recent scientific, industrial, technological, and information changes. Alzamil reported that, according to Searles (1983), 
These changes were beginning to transform civilization. Computers, television, and television networks, as well as videodiscs, became the center of this revolution. Society is becoming more digital, and technology became involved in all of life's aspects, including education. People, furthermore, started to look at everything, including education, through the "lenses" of technology. (Alzamil, 2003, p. 4)

In addition, technology became helpful in distance learning and e-learning. In other words, educators thought it was the "silver bullet" that would solve all problems.

Today, educators look at the use of technology in teaching and learning as a necessary part of enhancing education. Technology provides educators and students with different ways of connecting to larger world events. Technology has become an avenue through which teachers and students can simplify the procedures and techniques involved in acquiring knowledge and experience. Almallah (2010) identified some of the benefits in using technology, especially computers, in instruction. According to him, learners usually have positive attitudes toward computers and computer instruction. Technology helps learners through enhancing their main skills; technology improves learners' cognitive skills required in their learning activities; and technology greatly helps improve psychometric skills and affective skills. Technology is considered a tool to promote changes in student engagement (Almallah, 2010).

In most developed countries, including many Western countries, technology plays a vital role in the classroom. Alzamil mentioned that Sunal, Scheffler, and Sunal (1995) argued that technology would play a major part in reforming education, and they were right. Computers have ventured outside of traditional computer labs to be with students in their daily life activities. Furthermore, many of the objectives of education have changed and will continue to change due 
to computer technology. The teacher's role has also changed, as the teacher and the textbook are no longer the only sources of knowledge. Technology is expected to continue to modify and change the existing curriculum. It will lead to deeper student involvement in decision-making and the exploration of ideas (Alzamil, 2003).

With the integration of curriculum and technology, teachers will become most likely facilitators and supervisors of the learning processes rather than instructors. They will be organizers of student activities and facilitators of the learning process. Teachers will be focusing more on students' evaluation instead of being overwhelmed by content delivery.

Most Western educational establishments have begun to understand the educational implications accompanying these developments. Students no longer need to spend a great deal of their time traveling between classrooms. Students can now obtain undergraduate and even graduate degrees through e-learning and web-based instruction. This ability liberates students from time and distance restrictions that may have inhibited their learning previously; it has given them the opportunity to achieve their ambitions while keeping their jobs or living at home. Students can learn and then complete and submit assignments during their own free time. However, this does not mean that the teacher's role will be negated. Rather, the teacher will continue to be the organizer and supervisor of the educational situation in the classroom (Aloraini, 2005).

This educational avenue will enable students to have contact with others via different sources of knowledge rather than restricting them to just one source in the classroom. Technology has become a great adjunct for both the teacher and the students because of the broader scope that it encourages. 


\section{The Concept of E-learning}

E-learning is one of the most prominent avenues for using technology in education. In general, e-learning emerged from communications and information technology. It has become a major characteristic of the new educational generation, not only as an education source, but also as a means of communication through which teachers can interact with each other and with experts anywhere in the world (Almubirik, 2005).

Several scholars provided definitions of e-learning. Stockley (2003) defined e-learning as “the delivery of a learning, training or education program by electronic means. E-learning involves the use of a computer or electronic device (e.g., a mobile phone) in some way to provide training, educational or learning material" (para. 2). It involves the use of computers or electronic devices like the mobile telephone, etc. It is a fast growing way of learning with the help of computers and Internet connections (Stockley, 2003). In addition, Rosenberg (2001) defined e-learning as the use of Internet technology to deliver a broad array of solutions that enhance knowledge and performance (Rosenberg, 2001). Al-Khashab (2007) stated that Hall defined e-learning as instruction that is delivered electronically, in part or wholly, via a Web browser, through the Internet or an intranet, or through multimedia platforms such as a CD-ROM or DVD. All of these definitions serve as dimensions of e-learning, and all lead to the same meaning (Al-Khashab, 2007).

E-learning is a new education concept using the Internet technology to deliver digital content and provide a learner-oriented environment for teachers and students. E-learning promotes life-long learning and a learning society (E-learning, 2004). The American Society for Training and Development (ASTD) defines e-learning as a broad set of applications and processes that include web-based learning, computer-based learning, virtual classrooms, and 
digital media. Much of this is delivered via the Internet, intranets, audio- and videotape, satellite broadcast, interactive TV, and CD-ROM. The definition of e-learning varies depending on the organization and how it is used, but basically it involves electronic means of communication, education, and training (E-learning, 2010).

In summary, e-learning is a tool that can create a strong impetus for teaching and learning new educational methods. Government institutions and other organizations should support elearning and the teachers' ability to connect to outside resources. This connectivity will facilitate teacher training through the use of the Internet. In addition, such training introduces teachers to common problems and how to overcome them while providing time to learn this information and apply it in their classrooms.

Lately, a set of requirements and needs imposed by the conditions of the current educational era make e-learning, a major technological innovation, a strategic option. These specific needs include the need for continuous learning, the need for flexible education, the need to communicate openly with others, the need to learn based on one's interests, and the need for self-learning (Aloraini, 2005). The paradigm shift in learning, the application of modern theories of education development and improvement for teachers and learners, and the mastery of cooperative learning and individual learning make e-learning an important phenomenon. Elearning has a significant role in education because it supports both teachers and students in developing skills related to their interests, and it is essential for development and changes to curricula and programs on the Internet, including coping with specific requirements without significant additional costs (as was the case when developing programs on CD-ROMs). 


\section{E-learning and its Benefits to Education}

In 1902, Dewey observed that the education field needed to change because of the societal revolution taking place. He saw that this change in education would serve the new society and help meet the needs of the community. He understood that the learner needed to be engaged to make education a priority (Marcum, 2010). “As early as 1994, technology was mentioned as a tool to promote changes in student engagement" (Marcum, 2010, p. 17). Marcum provides additional information by quoting from a study that examined Apple Classrooms of Tomorrow (ACOT). The authors of the (ACOT) study reported that, "Technology-rich classrooms produce positive changes in student engagement, and further contended that conditions for sustaining student engagement include using technology within the context of meaningful assessment, while allowing for exploration and experimentation" (Sandholtz, Ringstaff, \& Dwyer, 1994, p. 8).

Some believe that learning using technology will be an essential requirement of life, and for that reason, preparing students to be effective in using technology will become a divisive issue. Bill Gates mentioned that significant changes will happen in education. Classrooms will remain for teaching, but the technique will change a lot of the details. Learning in the classroom will include multimedia presentations, and the assignment will include exploring electronic documents and studying texts. Furthermore, he asserted that teachers have to be strong believers in the use of technology to improve student learning and their production (Abdulkareem, 2009).

Midway into the 1990s, a proliferation of new information technology, such as the Internet and the World Wide Web (www), appeared as essential tools to improve the learning process and to prepare students for the future. Moreover, education was not viewed as being confined to a particular place, but was to be a wireless access for people anywhere and at 
anytime in the world. The knowledge was available to all categories of society. New schools are necessary for this educational revolution, and because the technology power is doubling every sixteen months, we have to keep pace with the new era of computer technology and communications.

Technology is a broad term that offers flexibility, accessibility, and convenience for courses (Alkhezzi, 2002). In today's society, we live in an educational environment where progress in communications technology has resulted in new forms of education such as elearning and computer-assisted teaching. These new forms aim to meet the needs of the learner through methods and techniques that rely on dynamic, transparent, and open dialogue. A feature of e-learning is the abolition of formal barriers and the elimination of spaces through the introduction of temporal flexibility and the creation of a new type of relationship between the student and the teacher (Niculescu-Aron, Asandului, Mazurencu, \& Mihaescu, 2007).

In general, technology-based tools can enhance student performance when they are integrated into the curriculum and used in accordance with knowledge about learning. But the mere existence of these tools in the classroom provides no guarantee that student learning will improve; they have to be part of a coherent education approach. (National Research Council, 2000, p. 216)

According to Sorensen, Mathiasen, and Dalsgaard (2009), e-learning technology provides new opportunities for development of education. It offers students access to courses wherever and whenever they would like or need, and by considering individual differences, it could replace tutors and private teaching. Uys discussed Lundin's argument (1993) that in some cases, the use of some types of e-learning such as Open and Distance Education (ODE) and 
Communication and Information Technologies (CIT) is better than face-to-face programs in relation to student satisfaction, achievement, and staff perceptions. ODE helps students understand their experiences through a combination of strategies that provides structure for information processing and for developing a conceptual understanding of the material being studied. "Methods based on ODE and CIT can be successfully applied to every part of every subject in any given curriculum" (as cited in Uys, 2000, p. 24).

A study by Falvo (1999) confirmed that the communication component of the Internet helps teachers and students improve their interactions. Additionally, the Internet offered a way to conveniently share and distribute instructional materials, and it provided valuable resources for the classroom. This technology links knowledge and learners and helps these learners create meaningful understanding. In fact, the increased interest in the use of the Internet in education has been evident through papers and presentations at national and international conferences. In October 2002, [International Data Corporation] IDC and [EDUCAUSE Center for Applied Research] ECAR surveyed 274 institutions that used e-learning. Most of the respondents (86\%) said they have implemented courses that use technology outside the classroom, and all have integrated technology into classroom-based courses. Eighty percent of the respondents said they offer hybrid courses that complement classroom sessions with virtual sessions, and $71 \%$ said they offer complete courses online. (Arabasz, Pirani, \& Fawcett, 2003, p. 9)

To guarantee the success of e-learning, communities have to change their views about elearning and come to see e-learning as an option that helps many of the students in developing countries get a better education. Ajarma (2007) mentioned that failure in the use of e-learning 
can occur because of misunderstanding its meaning and because of lack of planning. The success of e-learning also depends on conditioning academics for use of the e-learning strategy (Ajarma, 2007).

To conclude, as stated by Alzamil, several changes need to take place to ensure success in using technology in the classroom. To use computers as essential tools in instruction, teachers need to change the concept of their teaching role (Alzamil, 2003).

\section{Educational Application of E-learning}

The latest developments in the field of information technology set new patterns in education and training that clearly and strongly affect both education and training systems. People who are involved with or work in the educational field need a richly equipped educational environment that has newly designed learning potential and resources. With this concept in mind, educational institutions have to develop efficient educational systems capable of meeting the needs and requirements of the society. Consequently, there has always been increasing demand on facilitated, efficient, open, flexible, well-designed, and student-centered learning environments, and this has led educators to use e-learning (Khan, 2005). As cited in Khan (2005), Hall described e-learning as "the promising market which is the fastest growing in the field of education industry" (p. 16). According to the Hamprecht institution report, e-learning is on the threshold of explosion, and the institution expects its market to multiply annually by more than two in size starting from 2002 (as cited in Khan, 2005).

A large number of educators view e-learning as a sort of revolution in the field of learning methodology and educational technology that starts with the use of multimedia technology in learning and moves to depending upon self-learning, the basic mechanism of continuous learning. E-learning encompasses the building of hypothetical classrooms that enable 
learners to access lectures, symposiums, and forums held anywhere in the world through Internet technology. Theoretically speaking, e-learning creates a culture different from traditional culture because it focuses on processing knowledge and then benefiting from it by employing it in practical fields. This is contrary of the theoretical culture that focuses on knowledge production (Aloraini, 2005).

E-learning is considered one of the most important modern learning methods. It helps in addressing the problems of population and knowledge explosion and the accompanying high demand for education. Moreover, e-leaning is capable of widening and increasing the opportunities for admission to education by addressing the needs of a larger number of students who were blocked from joining educational centers and institutions, either because of living in geographically remote regions or because of the insufficiency and inadequacy of classrooms to accommodate a reasonable numbers of such learners (Almubirik, 2005).

E-learning is based on the principle of the individual's participation in educational activities. This, in turn, creates a positive learning atmosphere and stimulates the learner to continue studying. This is quite contrary to traditional learning methods characterized by stagnation and inactivity that lead to the learner's reluctance and unwillingness to learn. During the process of e-learning, the learner acquires and develops the skill of how to learn, and this guarantees life-long learning that drives the learner to develop his learning self and to make meaning of the information around him (Khan, 1999; Lal \& Aljundi, 2005).

E-learning is a form of distance learning, yet it is not the same as distance learning. Elearning can be introduced simultaneous with or side by side with the semester system according to a well-planned and well-organized system that has its inputs, processes, outputs, and feedback (Salem, 2004). According to experts, e-learning has gone through four phases: 
1). The first phase before 1983: Education was very traditional before the spread of computers in spite of the fact that some educators had computers. Communication between teacher and learner used to take place inside the classroom according to set timetables.

2). The second phase between 1984 and 1993: This phase can be referred to as the age of multi-media. It was characterized by the use of operating systems with drawn fronts as well as magnet discs as basic tools to develop education.

3). The third phase from 1993 to 2000: This phase was characterized by the advent of the Internet and then the appearance of e-mail and e-programs to operate and present video films.

4). The fourth phase from 2000 till now: This phase is characterized by the second generation of the Internet when the designing of sites on the net has become more advanced and has more powerful potential in terms of speed and content density (Salem, 2004).

\section{Methods of E-learning}

E-learning is performed by following two methods:

a). The simultaneous method that necessitates learners and teacher be present at the same time in order to secure direct and firsthand interaction between them, and b). The un-simultaneous method that does not necessitate learners and teacher be together at the same time. This can be done through various educational technologies, such as email, interactive video, chat rooms, and video conferences (Lal \& Aljundi, 2005). Teaching methodologies used in e-teaching systems differ from those used in the traditional educational system, with the former's main focus on the learner and the latter's on the 
teacher. The basic constituent of e-teaching is the programmed book and the Internet. The difference between the two systems led to a difference in the role the teacher plays in the educational process; the teacher's role has become somewhat secondary. This new role emphasizes planning and monitoring the educational process and assisting learners in using printed and programmed material through various technological and non-technological means.

\section{A Comparison between E-learning and Traditional Education}

There is no argument that e-learning is a good method to promote learning in the education field. Research shows that increasing the use of technology for learning has a positive effect on the student's commitment to the learning process (Lal \& Aljundi, 2005). The following table (Table 1) summarizes several opinions regarding the comparisons between e-learning and traditional learning. 
Table 1

Comparison between E-learning Approach and Traditional Approach (Saudi Arabia)

\begin{tabular}{|c|c|c|}
\hline & E-learning Approach & Traditional Learning Approach \\
\hline Teacher's role & $\begin{array}{l}\text { Teacher is a director of the } \\
\text { learning process. }\end{array}$ & $\begin{array}{l}\text { Teacher is a manager of learning } \\
\text { process. }\end{array}$ \\
\hline Location of learning & No fixed location for learning & $\begin{array}{l}\text { Learning usually happens at specific } \\
\text { places and teacher locations. }\end{array}$ \\
\hline Education system & $\begin{array}{l}\text { Learning happens in a very } \\
\text { open and flexible system. } \\
\text { Students can get needed } \\
\text { information any time or } \\
\text { anywhere. }\end{array}$ & $\begin{array}{l}\text { Learning happens in a limited } \\
\text { system with limited resources. }\end{array}$ \\
\hline Style of educational use & $\begin{array}{l}\text { Learning depends on } \\
\text { electronic media in a } \\
\text { supported environment by } \\
\text { providing schools for } \\
\text { students. }\end{array}$ & $\begin{array}{l}\text { Learning depends on specific } \\
\text { curriculum established by the } \\
\text { Minister of Education. }\end{array}$ \\
\hline Availability & $\begin{array}{l}\text { The availability of } \\
\text { technology for learners, any } \\
\text { time or anywhere }\end{array}$ & Limitation in resources for learners \\
\hline Learning responsibility & $\begin{array}{l}\text { Learning depends } \\
\text { individually on students or } \\
\text { learners. They have the } \\
\text { interests and ability to learn } \\
\text { the necessary topics and } \\
\text { studies. }\end{array}$ & $\begin{array}{l}\text { Learning depends on limited } \\
\text { courses. Students and learners do not } \\
\text { have choices of their courses, and } \\
\text { cannot select their interests. }\end{array}$ \\
\hline Possibility of updating & $\begin{array}{l}\text { Flexibility of updating } \\
\text { learning websites and } \\
\text { resources with less cost }\end{array}$ & $\begin{array}{l}\text { The inflexibility of updating } \\
\text { published books, in addition to the } \\
\text { difficulty and high costs of the } \\
\text { process }\end{array}$ \\
\hline
\end{tabular}

E-learning may fulfill the following objectives: (1) providing students with continuous feedback during the process of learning in order for them to know the extent of their progress; (2) providing the flexibility of contacts between students and teachers; (3) designing academic subjects and information using interactive multimedia that supplies students with entertainment and interaction while learning; and (4) addressing a lot of educational problems like the lack of 
an efficient system, individual differences, or looking at the teacher and the book as if they were the sole source of knowledge (Salem, 2004).

Additionally, e-learning helps cultivate the feeling of equality among all learners through communication tools that enable each student to voice his opinions freely at any time. E-learning gives all students the full opportunity to send their opinions and voice via available communication channels (Alhadi, 2005; Altawdri, 2004).

\section{Obstacles to Applying E-learning}

E-learning faces some obstacles. As Altawdri (2004) mentioned, despite the enthusiasm for e-learning, this kind of learning faces some obstacles that may be categorized as follows:

Human barriers. The success of e-learning depends on the human element, so a lack of training for teachers and technicians is one of the most important issues that impact faculty attitude toward the use of technology tools in the classroom. To overcome this obstacle, faculty must be provided with proper training to use e-learning in education. On the other hand, some students still prefer the traditional method of attending lectures and following lessons in textbooks. This preference for traditional methods is confined not just to students, but also to teachers (Salem, 2004).

A second issue is related to funding. A substantial investment is necessary to start a huge project like e-learning. An appropriate budget is required to purchase computers, software, Internet coverage, and other needed equipment. As we have seen, many of the developing countries found this model to be very costly to adopt.

Technical barriers. E-learning requires continuous maintenance of hardware and software. We know that there are certain indispensable requirements for e-learning as well as 
basic elements upon which this educational system is based. These elements must be integrated with one another for e-learning to succeed. These elements are as follows:

- Inputs of the e-learning system: These inputs are represented in the establishment of the infrastructure of e-learning. This infrastructure consists of computer sets, communication lines with the Internet, designing a website for the educational institution on the net, employing technicians to follow up the sets, designing electronic courses on sound scientific principles, preparing teaching halls equipped with computers, training teaching staff members and developing their technical skills, preparing students to change to e-learning, and finally to specify the educational objectives associated with the e-learning program.

- Operations of the e-learning system: These operations include practicing learning using electronic courses, students' following to the electronic lessons either simultaneously (inside the class) or non-simultaneously (at home or at work), using elearning techniques such as e-mail, interactive video, chat rooms, etc.

- Outputs of the e-learning system and feedback: These outputs are represented in making sure that the educational objectives have been achieved, student learning enhanced, weaknesses addressed, developing electronic course formats, arranging training courses for teachers and students when needed, and developing the institution's site on the net based on the results achieved (Salem, 2004).

Language barriers. Language is a major obstacle for many students and teachers in Saudi Arabia because the educational and research journals for most sites are published in English. A study by Alfleih (2004) presented some of the requirements that should be considered to apply e-learning. These requirements included building a specific vision for e-learning and 
developing a strategy for e-learning according to curriculum policy. The requirements also included preparing the infrastructure that includes computers, software, networks such as the Internet and the local net, and developing an interactive educational window to the Internet. This interactive window should contain the educational administration system, the school administration systems, interactive digital content in accordance with national content, systems of composing and designing educational units, testing and assessment systems, and enhancement systems.

These obstacles to e-learning increase and are more evident in developing countries. Alotaibi (2006) found that there were statistically significant differences in impediments to elearning education in when the students were female or were less experienced learners. Results also revealed that the curriculum density and its incompatibility with the constant developing of programs are impediments to the establishment of e-learning in Saudi Arabia. In addition, the speed of the communication network and the large number of students in one class further impede the application of e-learning in education.

Related to the same issue, Saadah and Alsartawi (2004) reported that Abdul Haq conducted a study entitled, "Obstacles Facing Teachers When Using Modern Technology.” The results of this study indicated that the most important impediments to teacher use of modern technology are lack of training in using modern technology, lack of future plans to use modern technology in the field of education, little time allocated for computer use, lack of programs and training on how to use the technology, and lack of technical support and maintenance (Saadah \& Alsartawi, 2004). 


\section{Teachers' Attitude toward the Use of E-Learning}

There have been great developments in the use of e-learning in the past few years, resulting in more attention being directed at computer-mediated communication. The potential of e-learning has created excitement among researchers and practitioners. Many educators and researchers had high hopes for e-learning, believing that it would provide more access to information and communication and would ultimately lead to a new revolution in education. Several studies have been conducted to examine attitudes toward e-learning in the West and other parts of the world (Al-Khashab, 2007).

An issue of concern is the preparation of teachers to use e-learning technology in their classrooms. Many studies have focused on the role of a lead teacher in the era of information technology and educational innovation. Information technology does not mean minimizing the importance of the teacher, or doing without the teacher as some people might believe. Instead, the use of technology means that the teacher assumes a different role than the one reflected in traditional education. This new role will vary depending on the educational endeavor. The teacher is no longer viewed as the sole source of knowledge, and in many respects, the teacher becomes a co-learner along with the student. The teacher serves the role of facilitator, advisor, and instructional designer and prepares activities for students that develop their research, decision-making, and problem-solving skills. These activities prepare students for a lifetime of learning. Therefore, it can be argued that quality instruction through e-learning relies more heavily on the abilities of the teacher than does learning through a more traditional approach (Almallah, 2010). Many studies have addressed this issue by emphasizing that quality and quantity of faculty training should be the first consideration in the development of online education. 
Doami and Alshannaq $(2006,2010)$ have argued that researching the use of e-learning in the classroom is more important than researching web applications in education. They mentioned that some faculty members are reluctant to use the Internet in education because of a lack of awareness of the importance of this technology. However, the success of e-learning depends on the capacity and efficiency of the teachers and their knowledge of using this technology to deliver educational programs. The university has a major role to play in creating the infrastructure necessary for e-learning to be successful (Alhajji, 2003).

Various studies (Berkowitz, 2000; Davenport, 2000; Falvo, 1999; U.S. Department of Education, 1999) indicated that teachers do not experience high quality professional development programs on a consistent basis and suggest that teachers need on-going technology training opportunities to further improve their skills and apply them to classroom learning. (Marcolini Hoover, 2003. p. 28 )

A large numbers of studies investigated the attitudes of educators toward the use electronic learning in teaching. They found that teachers' attitudes toward e-learning significantly improved after receiving training in the use of this technology. Some studies reported that attitude toward e-learning was influenced by the number of years of teaching experience and the number of hours of computer training the teacher had received (Alradadi, 2007; Al-Khashab, 2007; Arkin, 2003; Birisci, Metin, \& Karakas, 2009; Doami \& Alshannaq, 2010; Mehmet, 2005).

\section{E-learning in Teaching Mathematics}

The use of e-learning in teaching mathematics is one of the recent trends recommended by many studies because of its potential usefulness. Studies have reported that humans can 
remember $10 \%$ of what they read, $20 \%$ of what they hear, $50 \%$ of what they hear and see, and $90 \%$ of what they hear, see, and do. E-learning is recommended by many studies because it combines the auditory, the visual, and the practical in learning (Alradadi, 2007). Furthermore, the computer can play a crucial role in math teaching by providing the mechanism for combining the auditory, the visual, and the practical. It assists in explaining long mathematical concepts, and it attracts the attention of students and makes the learning of math an enjoyable experience (Saadah \& Alsartawi, 2004).

E-learning incorporates self-motivation, communication, efficiency, and technology. Therefore, distance is eliminated because e-learning content is designed with media that can be accessed from properly equipped computer terminals and other means of Internet accessible technology (Afaneh, 2006).

E-learning is a vital tool for teaching and learning mathematics effectively. Computer technology in mathematics education is effective in that it focuses on higher-order cognitive skills, such as investigating, reasoning, hypothesizing, and making generalizations (Karatas, 2011; Wiest, 2001).

Mathematics is a difficult subject for many learners, and educators need to be concerned about using technologies to make the study of mathematics more attractive to students (Bader, 2007). "Teachers should use technology to enhance their students' learning opportunities by selecting or creating mathematical tasks that take advantage of what technology can do efficiently and well - graphing, visualizing, and computing” (National Council of Teachers of Mathematics [NCTM], 2000, p. 25).

Al-Hareky (1983) investigated the effectiveness of modern educational technology in the teaching of elementary school mathematics in Saudi Arabia. The result of this investigation 
revealed a positive attitude among elementary school students toward instructional television. Also, the study showed a positive attitude among selected teachers toward the use of computerbased instruction and instructional television (Alzamil, 2003).

Technology enables users to explore topics in more depth. Examples might include interconnecting mathematics topics, writing programs, and devising multiple proofs and solutions. In more interactive ways, using simulations and data collection with probes, technology makes accessible the study of mathematics topics that were previously impractical, such as recursion and regression, by removing computational constraints. So many activities in mathematics could take advantage of the capabilities of technology and enhance learning beyond what could be done without technology. Technology facilitates the way for the student and teacher to access a great amount of information (Almallah, 2010).

"Technology-augmented activities should facilitate mathematical connections in two ways: (a) interconnect mathematics topics and (b) connect mathematics to real-world phenomena" (Garofalo, Drier, Harper, Timmerman, \& Shockey, 2000, p. 73). The authors also report that, according to the National Council of Teachers of Mathematics (NCTM), "Technology blurs some of the artificial separations among some topics in algebra, geometry and data analysis by allowing students to use ideas from one area of mathematics to better understand another area of mathematics" (NCTM, 2000, p. 26).

Many studies showed the effectiveness of web-based learning on mathematics. For example, Bader (2001) investigated the effectiveness of using the Internet to teach statistics in math classes in high schools. The results of the investigation show a positive attitude among high school students toward the web-based Internet (Alradadi, 2007). 
NCTM (2000) stated that the advent of computers and calculators in the classroom facilitates curriculum. By "using technological tools, students can reason about more general issues and they can model and solve complex problems that were heretofore inaccessible to them" (p. 26). Furthermore, technology can provide an exciting, innovative, and effective way for the learner to engage in mathematics practices (Shamatha, Peressini, \& Meymaris, 2004).

In conclusion, these studies agree that the use of electronic equipment in teaching mathematics can create a positive attitude toward math class and can enhance student learning. Finally, technology is essential to the teaching and learning of mathematics.

\section{Mathematics Teacher in E-learning Era}

There is no doubt that the use of e-learning has brought about a change in the teacher's role in the teaching and learning process. A quick comparison between the role of the teacher in the traditional setting and the role of the teacher in an e-learning setting reveals the following differences. The traditional teacher's role is one of a lecturer who introduces and offers the scientific content of courses to students and who is in full control over the educational process. The traditional teacher is the sole source of knowledge. On the other hand, the e-learning teacher serves as a guide and a facilitator of learning. The e-learning teacher is a member of a team who shares control of the educational process with students and other teacher team members (Alabbadi, 2002).

E-learning has redefined the teacher's role and turned it into a more important and complicated one. For the highly creative teacher who efficiently directs the educational process and works hard to achieve the expectations of progress using technology, this change will be accepted. Creative teachers will realize that their role has become more of a leader, a director, a facilitator, and a questioner. To grow along with the scientific and technological developments, 
the teacher should be equipped with an understanding of the developments in the technological sciences and the values associated with their use in modern society. Also, the teacher should not only master a set of scientific skills that enable him to produce simple scientific media using the audio-visual aids in teaching, but also master the use of the computer and employ it in the educational process.

As a result of e-learning, the role of the mathematics teacher has changed from the prompter of theories, axioms, and rules to that of a planner of educational situations and the designer of mathematics lessons presented through e-learning. Because the information that a mathematics student should know is varied and multitudinous, and because this particular subject requires a lot of mental effort because it is abstract, the role of the teacher has become one of encouraging learners to assimilate mathematical knowledge and find solutions to mathematical problems through varied electronic sources. E-learning in this case not only helps students solve complicated mathematical problems, but also encourages students to develop self-learning skills through searching for mathematical knowledge on the Internet. E-learning concentrates on the development of mathematical thinking as well as higher order thinking in general. In addition, the use of e-learning in teaching mathematics provides the teacher with the opportunity to move from teaching traditional mathematics to teaching mathematics to solve real life problems (Al Makoshi, 2001).

\section{Previous Studies on Using E-learning in Education}

Salamah and Abu-Raya (2002) examined the results of several studies that explored issues related to using computers in education. One of the studies reported was the research conducted by Mesbah Alhaj Essa in 1998. This study examined computer use in Kuwaiti secondary schools and found that practical training on computer sets was not enough to prepare 
teachers, despite the availability of computer sets and the suitability of training locations. In addition, the results indicated ineffective training courses that ranged between 1 and 6 hours. The research also reported that the majority of teachers believed that the computer sets available at schools and their accessories, like printers, are not sufficient (91\%). In terms of the software required for education to be effective, the study revealed that the software was not sufficient, whether it was a commercial product or produced at school. Teachers attributed the nonproduction of suitable software to their own lack of experience (as cited in Salamah \& AbuRaya, 2002).

Humaisat (1989) conducted a study on the use of computers in the governmental secondary schools in Jordan. The results of the study revealed that some computer science teachers were non-specialists $(56 \%)$ and that most teachers did not receive training in the use of the computer in the educational field. In terms of the availability of computer sets and their accessories at schools, the study showed that $70 \%$ of schools had one computer only, $20 \%$ had more than ten computers, and 3.3\% had more than 12 computers (as cited in Salamah \& AbuRaya, 2002).

Nakhla (1993) conducted a study entitled "The Reality of Using the Computer in Teaching Science in Secondary Schools." The results of the study indicated that the role of the computer in teaching science is ever growing. For example, from 1983 to $1984,85 \%$ of secondary schools used only one computer. Nakhla predicted that by the year $2000,25 \%$ of the secondary schools would have used the computer in education as a substitute for traditional teaching methods (as cited in Salamah \& Abu-Raya, 2002).

Becker (1985) conducted a study on the use of the computer in American schools. The study sample included 2,331 primary, middle, and high schools. The results of the study 
indicated that in 1980, half of the high schools had not used computers at all. By 1985, 90\% of the students in American schools were studying in schools that had at least one computer. All high schools had at least 20 computers each, whereas each primary school had six computers. Only $7 \%$ of high schools and $2 \%$ of primary schools recorded a suitable level of computer use in educational applications. In terms of the educational use of computers, the high schools dedicated $16 \%$ of the time allotted to learning to the computer as a tool that assists in the process of learning, whereas applied software occupied 50\% of the time allotted. In terms of teachers' use of the computer, results indicated that $52 \%$ of all teachers at schools included in the study used the computer regularly in teaching their students (as cited in Salamah \& Abu-Raya, 2002).

Khuleif (2001) conducted a study aimed at examining the importance of the computer and the properties that computers should have to produce educational aids. The researcher also examined the various uses of the Internet in the educational process, and the obstacles standing in the way of Internet usage. The study reported that the success of using the computer in the educational process depends on the factors of availability of computer sets and necessary programs, teachers' efficiency, computer flexibility in preparing and producing educational aids, and special programs designed to train teachers in the use of the computer as an educational medium.

Almohyssin (2006) examined the realities and the obstacles to computer use at colleges of education in Saudi universities in terms of the availability of computer sets, program peripherals, and staff members' use of such equipment. In addition, the study examined staff members' attitudes toward using the computer and the obstacles standing in the way of using them. A questionnaire was developed and administered to 200 male and female staff members from six colleges of education at Saudi universities. The responses to the questionnaire indicated 
that even though there were deficiencies in providing computer services, the faculty members held a positive attitude toward the use of computers in education. The study revealed that a lack of staff training on how to use the computer and the lack of computer technicians were the most important obstacles to using the computer effectively.

Abuaraad and Faseel (2006) examined the use of computers by faculty in teachers' colleges in Saudi Arabia universities. The study revealed that most of the faculty members included in the sample were average users and beginners in terms of computer use and computer experience. The study also revealed a positive attitude among the teaching staff members toward the use of the computer for educational purposes. There were some obstacles reported that negatively impacted the use of the computer in the teachers' colleges. One major obstacle was the lack of computer networks that could connect the departments of the college.

Mohammad (2004) examined pedagogical trends in the teaching of mathematics. The researcher examined two primary issues in her study. The first issue was the effectiveness of using cooperative learning strategies on increasing primary stage pupils' achievement in mathematics. The second issue was the development of secondary school mathematics curriculum according to individual student needs and international experience. The researcher suggested that computer study should not be optional and that all teachers should be trained on how to use the computer.

Alali (1996) investigated the design and development of a program to teach geometrical shapes to primary school fifth graders. The study also examined the effectiveness of teaching using a prepared program in comparison with traditional teaching methods. The study also explored the effect of computer assisted teaching on student achievement. The results of the study indicated that students in the experimental group showed highly positive attitudes toward 
the computer program. The results of the study showed that gender, in favor of female students, was an important variable in examining the achievement of learners in the control group. The study also showed no statistically significant differences in attitudes toward the computer program between male and female students in the experimental group.

\section{Experiments on Use of E-Learning}

A study by Lal and Aljundi (2005) sought to identify education technology and its importance in developing and enhancing the educational process. The study examined what was considered to be pioneering experiments in the field of applying different systems of e-learning to the educational process. The following is a summary of some of the experiments.

In 1995, the Japanese began what is known as the One Hundred School Project. Schools were prepared to test and develop educational activities and software via the Internet. An educational policy committee was formed, and the Ministry of Education suggested that a provincial information system be created to serve lifelong education in every Japanese province. The Ministry of Education was to provide a center for educational software and a national information center. The educational policy committee created the plans necessary for training teachers and members of the educational organizations on this new educational technology. It is worth mentioning that Japan is considered one of the countries that officially apply the methods of modern e-learning in most of their schools.

In a practical study performed in 1993, it was revealed that $98 \%$ of American primary and high schools had a computer set for every nine students. At present, the computer is $100 \%$ available in all United States public schools. In 1995, all states completed their plans for computer applications in the field of education. These states were interested in training teachers and in providing the infrastructure necessary for schools to be connected with each other. 
The Ministry of Education and Youth in The United Arab Emirates adopted a project for the development of computer curricula in the secondary school stage. This project began in 1990 and included the first and the second grades of the secondary school stage. The project began with the preparation of the computer syllabus of the first grade and testing it in two secondary schools in each educational region. In the following year, this experiment was expanded to include all secondary schools in the country. This experiment resulted in the following: (1) showing parents' awareness of the importance of computers in our modern life; (2) encouraging teachers of other subjects to learn computer skills; and (3) encouraging the school administration to use the computer in managing the school's affairs; this prompted the Ministry of Education to launch computer initiatives in school administration.

As a result of these experiments, it was agreed that teaching computer science begin in the middle and secondary stages. Alsunbol et al. (2004) examined the phases of educational innovation in Saudi education. The Ministry of Education's application of "The National Project of Using the Computer in Education" is explored in this examination. This project is based on learning about the computer both theoretically and practically, using it for learning, and using it for collecting information and data. This national project aims at achieving the following objectives:

Objective One: Qualifying students to coexist with a developed technical environment in which the computer and information systems form an essential basis.

Objective Two: Spreading computer culture among students, teachers, and the rest of society.

Objective Three: Using the computer as an ideal educational medium for teachers and students alike. 
Objective Four: Coordinating the different information channels and getting them to serve the educational process.

Objective Five: Developing teachers' skills in the field of integrating information technology into classroom and non-classroom activities.

Objective Six: It is worth mentioning here that the national project with all its objectives does not diminish the role of the teacher. Instead, the teacher's role is changed from one of a prompter of information to that of a developer of educational activities and processes using technology that engages students in their own learning and where the focus is on student learning.

Alhadi (2005) examined the approaches used by the Malaysian government in launching e-learning. In 1996, the Malaysian Comprehensive Development Committee set forth a comprehensive technical plan that was designed to place education in that country among the best in developed countries. This plan was given the name "Vision 2020." One of the most important objectives of this plan was to make the computer available and to connect it to the Internet in every class. The Malaysian schools that apply this technology are called "intelligent schools," and Malaysia is one of the countries that gave top priority to information technology. All schools and universities were connected to a backbone of speedy visual networks that would accommodate information sets to be adapted to transfer multimedia and video, and to enable 8,000 students in one hundred schools to attend classes via e-books. Educational authorities expressed their hope to make e-books replace traditional books by 2007 (Alhadi, 2005).

\section{Studies on E-learning and its Use in Teaching}

Almoussa (2002) investigated the concept of e-learning, its characteristics, its potential benefits and advantages, and the obstacles that hinder its adoption. The recommendations from 
the study were that educationalists should support the application of that sort of learning (elearning). A second recommendation discussed the importance of securing the infrastructure necessary for e-learning implementation and the necessity of preparing well-qualified faculty and support staff. Training programs for students, teachers, and administrators were deemed essential to realize the maximum benefit from the technology represented in e-learning.

Almohyssin (2002) undertook a study aimed at defining e-learning and specifying its most important terminology such as e-learner, e-teacher, e-school, e-library, and e-book. The researcher also tried to isolate the proper methods to invest in and exploit this sort of education in educational institutions. The study concluded that e-learning will be crucially important in providing opportunities for learners to acquire the necessary skills for the future. It was thought that e-learning could open new horizons for learners because it would make education available to meet the intellectual and cultural needs of future students.

Aljurf (2006) conducted a study of the effectiveness of e-learning in teaching English at the university level in the Kingdom of Saudi Arabia. This study sought to determine if there were statistically significant differences in the achievement of female students who were trained in writing English using the traditional method (this method depended on the book used inside the class) and the achievement of poor female students who studied the same course using the traditional method and the e-method together. The study showed that using an e-course side by side with a traditional course in teaching the writing skills of English to first-year female students at the College of Language and Translation at King Saud University resulted in improving poor students' ability to write English. E-instruction was determined to be important in the teaching of English to university level students. It was recommended to start offering e- 
instruction by producing e-courses and publishing them on the Internet in the various specializations in general and the English language in particular.

Alharbi (2006) examined the demands of using e-learning to teach secondary stage mathematics from the perspective of the practioner and the specialist. There were no significant differences between the responses of the practioners and specialists in terms of the importance of planning, implementation, and evaluation. There were no significant differences in practioners' and specialists' responses to the demands of implementing e-learning based on years of experience.

Alzahrani and Yamani (2008) conducted a study examining the future of e-learning in Saudi higher education in which they examined key issues related to the role of higher education in a time of rapid technological development. The study also examined challenges faced by higher education in relation to e-learning and its actualization in higher education.

Recommendations from this study highlight the importance of coordination and cooperation in planning and developing higher education to encourage the development of new patterns and forms of education because these new opportunities will play a vital role in raising the level of higher education through increasing access to educational programs.

Alsufeani (2008) sought to identify the degree of importance and use of e-learning in teaching high school mathematics as reflected in the views of teachers and supervisors in public schools. The researcher was interested in whether the views of teachers and supervisors differed significantly according to the variables of age, level of educational, job specialization, years of experience, and course training. This descriptive study included a random sample of 160 teachers and 40 supervisors. There were no statistically significant differences at the .05 level of significance between the score averages of the two groups in terms of the importance and use of 
e-learning when examined on the variables of age, educational level, course training, and years of experience. All participants in the study were positive in their views that e-learning was important and that the use of this technology was fairly good. This study further recommended that training opportunities be provided for mathematics teachers and that all computer labs be equipped to meet e-learning requirements.

A study evaluating e-learning materials used in teaching a physics course in Jordanian secondary schools was conducted by Doami and Alshannaq (2006). The main objective of this study was to survey teachers and students on what they considered to be the most important problems and hindrances during a physics course. The study sample consisted of 28 teachers (males and females) who taught computerized physics to secondary school first year students and 118 students distributed among five groups, four of which were in the experimental group and one in the control group. Results indicated that one of the most important problems and hindrances that teachers encountered in implementing e-learning was the lack of a computer lab for the science subjects. The time of the science class always clashed with the time of the computer class. In addition, schools lacked Internet service, and the number of computers at the schools was not sufficient for the number of students. The lab services were also not up to the standard required because of the lack of printing paper and loudspeakers. The number of students inside the lab was high, and there were not sufficient technicians to assist in the computer lab. Students, too, faced almost the same problems in e-learning because of the lack of a science lab and the large number of breakdowns involving the computer and the Internet. Moreover, the number of computer sets at the school was insufficient, and the school was not connected to the Internet. Students were not allotted the time required to browse for programs relevant to the courses taught. 
A study by Zein Aldein (2006) investigated the effect of an e-learning experiment in Egyptian prep schools on students' academic achievements. The study also built a scale to measure Egyptian prep school students' attitudes toward e-learning and their acceptance of the elearning program. The study used descriptive, analytical methods along with experimental methods. The study sample was intentionally selected and was confined to students who were willing to participate. Those were 112 third-year prep school students belonging to three schools in Port Said Province in Egypt. This study had six major findings. The first finding reported the necessity of training teachers on employing and using the e-learning pattern and making them aware of the need to share and exchange their experience in this field with those who lack such experience. The second finding reveals that establishing an e-learning department inside the Ministries of Education and Higher Education is important. The third finding was related to providing more schools with computer sets, particularly the prep schools. A fourth recommendation asked colleges of education to launch an e-learning major or specialization. The fifth recommendation concerned the necessity of upgrading the efficiency of the e-connection networks required for e-learning. The final recommendation addressed the need to package computerized courses and programs on CDs and distribute them to students along with the printed books before the full application of the e-learning system.

Alattarji (2002) conducted a study in which an Experimental Hypothetical Internet ESchool was to be launched and established as a hypothetical, experimental, Saudi secondary school on the Internet. This school would be affiliated with the Ministry of Education and would support traditional secondary schools as well as night schools, home taught students, children of those with scholarships outside Saudi Arabia, and finally, anyone who wanted to benefit from this pioneering experiment. 
The result of this study focused on the importance of many factors. The Ministry of Education had to form a highly specialized team to assume the responsibility for this hypothetical, experimental, Saudi Internet secondary school. This team established this school, defined its objectives, set its e-courses and programs, put these courses on CDs, and defined admission regulations and conditions in order for the applicant to obtain an accredited certificate from the school administration. Because computer-assisted learning tends to be theoretical, the researcher suggests that the academic side be in the form of video shots that can be watched by the learner with some sort of guidance and direction. These shots and video scenes are able to stimulate learners, attract their attention, and fire their imagination. The school site on the Internet should contain a forum or a club through which people could exchange written or oral messages, pool ideas, and exchange opinions on the different subjects of the e-courses.

Alhasnawi (2007) conducted a study comparing the effect of using some e-learning techniques, such as the video, CDs, data show, the Internet, computer programs, in teaching the basics of electronics. The study examined the impact using these e-learning techniques on student achievement and scientific thinking. The study sample consisted of 100 first grade male and female students attending the Department of Electric Technology at Al Nasseriah Technical Institute, which was affiliated with the Department of Technical Education in Iraq during the academic year 2007-2008. Those students were divided into four experimental groups. Experimental research methods were used. Results showed that group four, which included students who used the Internet, excelled and scored better than group three, which included students who used computer programs individually, and also better than group two, which included students who used data show, and better than those in group one, which included students who used the video CDs. 
A study by Bader (2001) explored designing web pages according to educational and pedagogical considerations and then measuring the effectiveness of using the Internet to deliver the designed pages in teaching a statistics unit. Results indicated that the Internet was quite effective in this respect. The study also recognized the importance and the necessity of using the Internet in teaching mathematics in the secondary stage.

Gerber and Shuell (1998) conducted an investigation into the best methods to employ in using the Internet to teach mathematics. A random sample of eighth year students participated in this study over a period of five weeks. This study reached the conclusion that students recognized the importance of the Internet as an effective means to collect data related to mathematics. In addition, students were positive toward the importance of the Internet in the applications to their daily lives.

\section{Comments on Previous Studies}

Previous studies can be classified according to the subject examined and to the results reached by these studies. In terms of subject matter, the researcher tended to classify previous studies into three categories:

1). Studies approaching computer educational use (Abuaraad \& Faseel, 2006; Alali, 1996; Almohyssin, 2002; Bader, 2001; Khuleif, 2001).

2). Studies approaching the reality of e-learning and its employment in teaching (Alattarji, 2002; Alhasnawi, 2007; Aljurf, 2006; Almohyssin, 2006; Almoussa, 2002; Bader, 2001; Doami \& Alshannaq, 2006; Doami \& Alshannaq, 2010; Gerber \& Shuell, 1998; Zein Aldein, 2006).

3). Studies approaching pioneering international experiments in e-learning (Alsunbol, Alkhateeb, Metwalli, \& Abduljawad, 2004; Alhadi, 2005; Lal \& Aljundi, 2005). 
The most important results of the previous studies were as follows:

- Teachers, especially secondary school teachers and university teachers, have a strong inclination towards using e-learning.

- Both male and female students revealed a strong inclination towards using e-learning.

- Students who registered in an e-learning program revealed noticeable improvement in their performance, academic achievement, and thinking behavior.

- E-learning is capable of improving the educational process, enriching the educational system in general, and giving it a strong push forward.

- It is crucially important to prepare teachers before starting to apply that sort of education.

- Educational institutions should be well prepared before launching this sort of education (e-learning), and the same thing is true of school principals, teachers, computer technicians, and computer programmers.

- It is important to reduce the obstacles to e-learning to a minimum.

- It is important to learn from experiments conducted in countries that are more advanced in the use of the computer in education. 


\section{Introduction}

\section{CHAPTER 3}

\section{METHODOLOGY}

This chapter presents the methodology used in this research. The first section presents the research design that outlines the scope of the study, the sources for collecting data, and how the study was conducted. The second section identifies the population for the study, indicates the site for collecting data, and specifies the participants. The third section describes the instrumentation used to collect the data. The fourth section explains the procedure used in data collection and the methods used to analyze the data. The fifth section presents the limitations of the study that may hinder generalizing from this research. The last section presents the methods used in analyzing and interpreting the data.

\section{Research Design}

The purpose of this study was to investigate the status of the integration of e-learning in the teaching of mathematics by female teachers in selected high schools in Saudi Arabia. This study was also designed to determine if there were real obstacles, if any, to adopting e-learning and instructional technology in girls' high schools in Saudi Arabia. To accomplish this objective, the researcher conducted a study among female math teachers in the city of Tabuk, Saudi Arabia. The study employed both quantitative data gathering methods and statistical test analyses, supported by qualitative data and content analysis.

The researcher investigated the current state of the use of educational technologies in the schools involved with the study. The findings and recommendations from previous research on the use of e-learning in the teaching of math were explored. 


\section{The Population}

The population of the study consisted roughly of 200 female math teachers at Tabuk General Directorate of Education, Saudi Arabia, during the academic year 2007-2008. It is worth mentioning that Tabuk Province is one of the largest provinces in terms of size and population growth in Saudi Arabia (Saudi Arabia has 13 provinces). In addition, in the past, more studies were focused on Riyadh and Jeddah because they represent the most popular cities in Saudi Arabia. Tabuk was selected as the site of this study because it is involved in implementing elearning technologies. Furthermore, the researcher is familiar with the province and was able to communicate with the people in charge when the survey was distributed and collected.

\section{The Sample}

The total sample of the study is 70 teachers selected randomly from the total population of female teachers in the secondary schools in Tabuk. The researcher obtained permission from General Directorate of Girls Education in Tabuk, Saudi Arabia, to allow her to schedule visits to schools and distribute the questionnaire (Appendix A). The survey was translated into Arabic, for the targeted sample language is Arabic (Appendix B). Sixty-two of the teachers in the sample completed and returned the questionnaire to the researcher.

\section{Instrumentation}

The researcher used a 5-point Likert scale questionnaire to collect the data. Using a questionnaire developed, tested, and used by Alzamil (2003), the researcher modified the instrument to reflect using e-learning in teaching math in Saudi secondary schools.

The instrument consisted of three parts: personal information, measurement of teachers' attitudes, and computer training and lab availability (IT literacy). The following are details of the components of the instrument: 
Part one: Personal information. The personal information measured in this study included the following:
a. Teaching experience: $0-5$ years $6-10$ years $11-15$ years 16 years or more
b. Education level: Diploma Bachelor High Diploma Master Doctoral

Part two: Measurement of teachers' attitude. This part consisted of 27 statements describing teachers' attitudes towards the use of e-learning. The variables were measured by a 5point Likert scale $(5=$ strongly agree and $1=$ strongly disagree $)$.

Part three: Computer training and lab availability (IT literacy). In this section, the instrument focused on the subjects' usage of computers and Internet at home and at school. Additionally, it focused on their training in integrating e-learning in their classrooms. Finally, it examined the availability and accessibility of the Internet and computers at school. The validity and reliability of the questionnaire were tested to make sure that it was scientifically useful for the research. Validity refers to the defensibility of the inferences researchers make from the data collected through the use of an instrument. A reliable instrument is one that gives consistent results (Fraenkel \& Wallen, 1990). The validity and the reliability were checked in different ways. First, the content validity was checked; the clarity and readability of the questions were tested several times before the instrument was distributed. The items of the instrument covered all aspects of the study. The content-related evidence was checked and reviewed by a number of experts in the field (professors of the Department of Curriculum and Instruction in Tabuk University) to identify proper questions. Their feedback was helpful in adding more questions, deleting irrelevant questions, and making necessary adjustments to other questions. It was an advantage for the researcher to use an instrument that was developed and used previously; the instrument was used in a doctoral degree study, and its validity was tested. Finally, the researcher 
estimated the items for homogeneity of the survey using the formula that test validity $(v)=$ square root $(r)=.85$. The reliability coefficient was estimated by Cronbach's alpha which was .73. This procedure was used to estimate the intrinsic validity of the instrument.

\section{Data Collection}

The data were collected from 14 high schools in Tabuk Province (Saudi Arabia); the participants, as stated above, were selected at random and provided with a paper survey. Because the researcher obtained permission from the Director of Tabuk Directorate of Education to distribute the questionnaire manually for faster processing, the answers were returned to the Directorate of Education and handed to the researcher within a month.

\section{Limitations}

Like all other studies, this study has its limitations.

First, the study cannot be generalized to the entire teacher population because it focused only on female teachers of mathematics.

Second, the study is limited to the Tabuk area and cannot be generalized to the whole Kingdom.

\section{Data Analysis}

The use of descriptive statistics has advantages. According to Fraenkel and Wallen (1990), “...the major advantage of descriptive statistics is that they permit the researcher to describe the information contained in many scores with just a few indices such as the mean or median" (p. 57).

The data collected from the questionnaire were coded for computer handling and analyzed using the Statistical Package for Social Sciences (SPSS) version 11.0 software. Norusis (1999) and Foster (1998) stated that before any analysis was done, raw data were to be keyed 
into the questionnaires and later exported to SPSS software for analysis. To answer the first study questions, the researcher utilized descriptive statistics including means, standard deviations, ranges, frequencies, percentages, and diagrams. Frequency distribution graphs were used for the quantitative data. In addition, a pie chart was used to indicate the categorical responses of participants. The frequency distributions were compared by the user's group membership (e.g., student or faculty member). Bar charts and tables were used to display the results. The comparisons were made based on the responses of participants to the items under the major four issues (i.e., years of experience, level of education, computer courses training, and computer lab availability). Eventually, a $t$-test for statistical significances was employed to test the level of significance. 


\section{CHAPTER 4}

\section{Introduction}

\section{RESULTS OF THE STUDY}

This chapter presents the analysis of the data collected from the administration. A 5-point Likert scale questionnaire was offered to 70 female mathematics teachers from 14 high schools in Tabuk Province, Saudi Arabia. Of the 70 teachers included in the sample, 62 completed and returned the questionnaire. The questionnaire was constructed to collect data in three categories, i.e., (1) personal information, (2) attitudes toward the use of e-learning in teaching mathematics, and (3) computer training and computer lab availability.

The data collected from the questionnaire were coded for computer handling and analyzed using the Statistical Package for Social Sciences (SPSS) version 11.0 software. The data are summarized and presented in the forms of means, standard deviations, ranges, frequencies, percentages, tables, and diagrams. Frequency distribution graphs were used for the quantitative data, and pie charts were used to indicate the categorical responses of the participants. The collected data were analyzed using descriptive statistical methods. The $t$-test was used to test for the level of significance. Comparisons of the data were made based on the responses of participants to the items related to years of experience, level of education, computer course training, and computer lab availability.

\section{Validity and Reliability}

The validity and reliability of the questionnaire were tested to insure that it was scientifically useful for this research. The questionnaire was checked for content validity by experts in the field from Tabuk University. This review resulted in some items being dropped, some added, and the clarity and readability of the items being carefully checked. The researcher estimated the items for homogeneity of the survey using the formula that test validity: $(v)=$ 
square root $(r)=.85$. Therefore, the scale validity of .85 meant that the scale had high intrinsic validity and that the test was a valid scale/test to measure female mathematics teachers' attitudes toward the use of e-learning in teaching mathematics in high school. Cronbach's formula, used to estimate the reliability of the scale, produced a value of .73 , indicating that the scale items were accurate and homogeneous.

\section{Research Questions}

The study consisted of three research questions (RQs), with the third question generating four research hypotheses. The research questions are as follows:

RQ 1: What are the attitudes held by female high school math teachers toward the use of e-learning in teaching mathematics?

RQ 2: To what extent do female math teachers believe that the use of e-learning in high schools supports education?

RQ 3: Are there any statistically significance differences among female math teachers' attitudes toward the use of e-learning in teaching math when examined for the following variables:

a). academic degree,

b). years of experience,

c). computer courses training, and

d). computer lab availability?

The research hypotheses used to examine the third question of the study are as follows:

RHo1: There are no statistically significant differences at the .05 level between the teachers' attitudes toward e-learning and their academic degrees. 
RHo2: There are no statistically significant differences at the .05 level between the teachers' attitudes toward e-learning and their years of experience.

RHo3: There are no statistically significant differences at the .05 level between the teachers' attitudes toward e-learning and their computer course training.

RHo4: There are no statistically significant differences at .05 level between the teachers' attitudes toward e-learning and computer lab availability.

\section{Results}

Demographic information. This study examined the attitudes and responses of 62 female mathematics teachers toward the use of e-learning in teaching mathematics in high school. The responses to the questionnaire were examined in relation to the variables of years of teaching experience, academic degree, computer course (IT) training, and computer lab availability. The number of teachers and the corresponding percentages for each of the variables are presented in Tables 2-5 and Figures 1-3.

As can be seen in Table 2 and Figure 1,77\% of the teachers included in the sample had 10 years of teaching experience or less. Only $23 \%$ had more that 11 years of teaching experience. 
Table 2

Years of Teaching Experience

\begin{tabular}{|l|l|l|}
\hline Experience in Years & $N$ & Percent (\%) \\
\hline Less than 5 & 14 & 22.6 \\
\hline $5-10$ & 34 & 54.8 \\
\hline $11-15$ & 8 & 12.9 \\
\hline More than 16 & 6 & 9.7 \\
\hline Total & 62 & 100 \\
\hline
\end{tabular}

\section{Years of Experience}

\section{- Less than $5 \quad$-6-10y $\quad 11-15 y \quad$ More than $16 \mathrm{y}$}

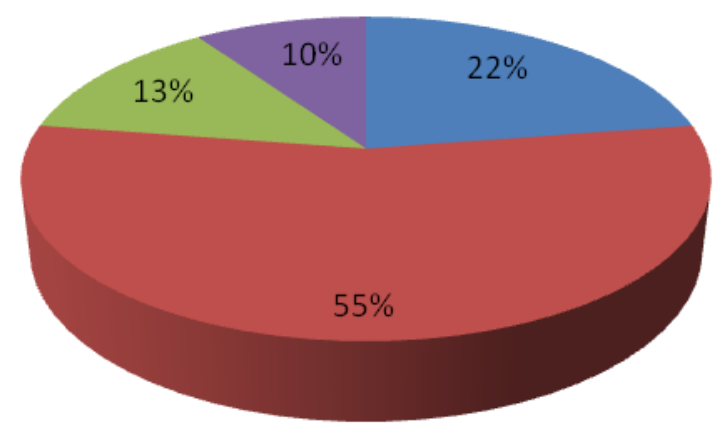

Figure 1. Years of teaching experience for participants.

The academic degrees of the participants are displayed in Table 3. It shows that $98.4 \%$ held a bachelor's degree and only one participant had earned a master's degree. 
Table 3

Academic Degree of Participants

\begin{tabular}{|l|l|l|}
\hline Academic Degree & $N$ & Percent (\%) \\
\hline Diploma & 0 & 0 \\
\hline Bachelor & 61 & 98.4 \\
\hline Master & 1 & 1.6 \\
\hline Higher diploma & 0 & 0 \\
\hline Ph.D. & 0 & 0 \\
\hline Total & 62 & 100 \\
\hline
\end{tabular}

The percentage of teachers in the sample who had computer course (IT) training is presented in Table 4 and Figure 2. The sample was fairly evenly split between those teachers who had training (46.8\%) and those who had not received computer training (45.2\%).

Table 4

IT Course for Participants

\begin{tabular}{|l|l|l|}
\hline IT Courses Training & N & Percent (\%) \\
\hline Trained & 29 & 46.8 \\
\hline Non-trained & 28 & 45.2 \\
\hline Non-identified & 5 & 8.1 \\
\hline Total & 62 & 100 \\
\hline
\end{tabular}




\section{IT Course Training}

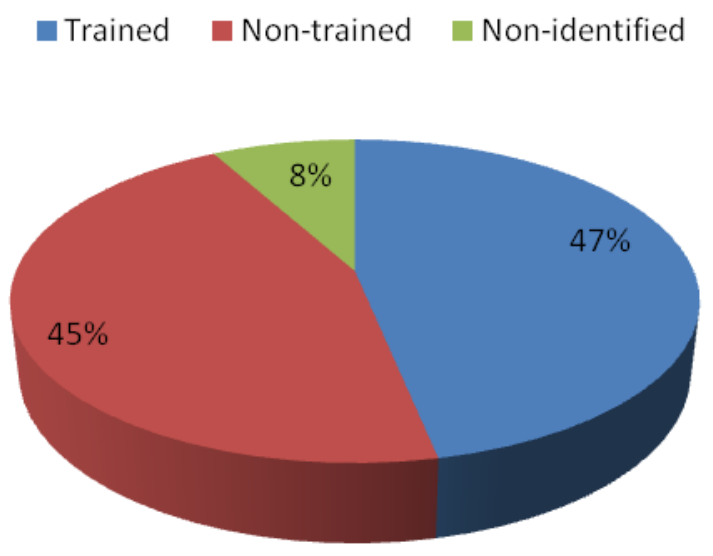

Figure 2. IT course training of participants.

The numbers of the teachers who had computer lab availability are presented in Table 5 . This table shows that $82.3 \%$ of the teachers in the sample indicated they had computer lab availability.

Table 5

Availability of Computer Lab

\begin{tabular}{|l|l|l|}
\hline PC Availability & $N$ & Percent (\%) \\
\hline Available & 51 & 82.3 \\
\hline Unavailable & 9 & 14.5 \\
\hline Non-identified & 2 & 3.2 \\
\hline Total & 62 & 100 \\
\hline
\end{tabular}




\section{Lab Availability}

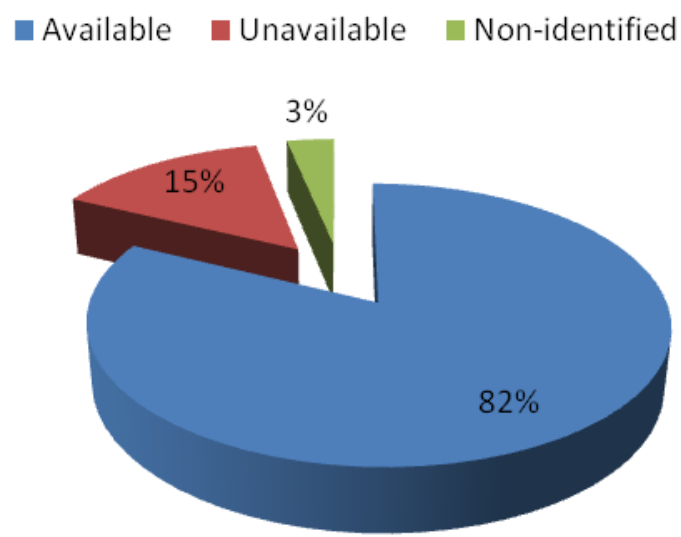

Figure 3. Computer lab availability.

Research question one. RQ1 1 asked, what are the attitudes held by female high school math teachers toward the use of e-learning in teaching mathematics? To answer this question, a 5-point Likert scale was used to assess high school female mathematics teachers' attitudes toward the use of e-learning in teaching mathematics. The scores for responses to the attitude scale are reported in Table 7 (Appendix C). The highest mean score reported was 4.3 for item 25, "E-learning enriches the educational process." Over $87 \%$ of the respondents agreed with this statement. This finding is consistent with the research reported by Aljurf (2006).

In addition, Table 7 (Appendix C) presents several items on the attitude scales that received mean ratings of over 4.0 and were agreed to by over $80 \%$ of the study participants. These items were as follows:

- "Using e-learning makes teaching more effective,"

- "Using e-learning in teaching math improves the quality of teaching,"

- "Using e-learning in the classroom makes teaching interesting," 
- "Using e-learning in teaching helps me to organize my work,"

- "I prefer using e-learning in teaching math," and

- "Using e-learning is a good tool to improve my teaching."

Several questionnaire items received mean ratings from 3.1 to 3.9 with measures of agreement from $70 \%$ to $79 \%$. These items are reported in Table 7 (Appendix C) and are as follows:

- "I am enthusiastic about teaching math using e-learning,"

- "Using e-learning urges me to perform with excellence,"

- "Using e-learning helps me in teaching math,"

- "Using e-learning improves my performance level in teaching,"

- "I feel confident when I teach using e-learning," and

- "Using e-learning makes me feel comfortable."

In addition, two other questionnaire items received mean ratings of over 3.0. "Using elearning helps me to cater to individual differences among students" received a mean rating of 3.5 with $53 \%$ agreement. "I prefer using e-learning instead of using traditional methods in teaching math" received a mean ranking of 3.1 with an agreement rate of $41 \%$.

Ten items on the questionnaire were stated in the negative so that the responses to these items might provide additional information that could be used to check whether the participants' attitudes toward the use of e-learning in teaching math were consistent across items. An example of such an item is "Using e-learning in teaching math is boring." The mean ranking of this item was 2.2 , with $6.4 \%$ agreeing compared with $66.1 \%$ who responded as "Don't Agree." These 10 items with the corresponding mean ratings and percentages are reported in Table 7 (Appendix C). The numbers for these items are 2, 5, 7, 10, 12, 13, 16, 18, 19, and 22. The low mean rating 
for these 10 items reinforces the positive attitudes toward the use of e-learning reported for the remaining items of the questionnaire. These results were in agreement with the findings of previous studies on teachers' use of e-learning (Abuaraad \& Faseel, 2006; Almohyssin, 2006).

Research question two. RQ 2 asked, to what extent do female math teachers believe that the use of e-learning in high schools supports education? Data collected for items 3, 4, 20, 24, and 25 on the attitude questionnaire were used to answer this question. These items were formulated to gather data from female high school math teachers and their perceptions of the effectiveness of e-learning in supporting the education of students. The results are reported in Table 7 (Appendix C).

Of the five items on the questionnaire that addressed RQ 2, item 25, "E-learning enriches the educational process," produced a mean of 4.3, the highest mean for any item in the survey. Item 25 also had $87.1 \%$ agreement among the teachers. Item 20, "E-learning in teaching math improves the quality of teaching," produced a percentage of agreement of $83.9 \%$ and a mean of 4.1. Item 4, "Using e-learning makes teaching effective," produced a mean of 4.1 with a percentage of agreement of $80.3 \%$, and item 3, "Using e-learning is a good tool to improve teaching," produced a mean of 4.0 with $74.1 \%$ agreement. Finally, item 24 asked the participants if the use of e-learning helped them to address the individual needs of students. The teachers' responses to this item produced a mean of 3.5 with a $53.2 \%$ agreement.

Generally, the high percentages reported for items 3, 4, 20, 24, and 25 indicate that female high school math teachers held a positive attitude for the role that e-learning can play in education. These findings are consistent with previous research findings that e-learning is seen as effective in education and improving students' academic achievement (Alali, 1996; Alhasnawi, 2007; Aljurf, 2006; Bader, 2001). 
Research question three. RQ 3 asked if there were any statistically significant differences among female math teachers' attitudes toward the use of e-learning in teaching high school math when analyzed for the variables of academic degree, years of experience, computer course training, and computer lab availability. Four research hypotheses that were examined to answer RQ 3.

Research hypothesis one. The results of the analysis of research hypothesis one are presented in Table 8 (Appendix C). No significant differences were found in the mean ratings of the teachers' attitudes toward the use of e-learning based on their academic degrees. With one exception, all of the teachers held a bachelors degree. There were not sufficient numbers across the degree categories to produce meaningful comparisons.

Research hypothesis two. The results of the analysis of research hypothesis two are presented in Table 9 (Appendix C). No significant differences were found at the .05 level of significance in the mean ratings of teachers' attitudes toward the use of e-learning and number of years of teaching experience. E-learning is a relatively new experience for female teachers in Saudi Arabia, and this may account for the lack of differences when examined for years of experience.

Research hypothesis three. There were no statistically significant differences found at the .05 level of significance between the teachers' attitudes toward e-learning and their computer courses training for all items except for questionnaire item 20. The analysis of item 20, "Elearning in teaching math improves the quality of teaching," produced significant differences when examined using the $t$-test of significance.

The results presented in Table 10 (Appendix C) show that there are no statistically significant differences at the .05 level between the teachers' e-learning attitudes and their in- 
service training (trained or not trained). This means that almost all teachers have the same attitudes toward the use of e-learning in education. Although there was a significant difference in teachers' responses to item 20 , the rest of the scale items showed no significant differences. This result may be due to the fact that no in-service training courses were offered to the teachers in relation to e-learning.

Research hypothesis four. There are no statistically significant differences at the .05 level of significance between the teachers' attitudes toward e-learning and the availability of computer labs (i.e., available or not available). Pearson's correlation coefficient was calculated on lab availability and teachers' total response to the scale items.

The results presented in Table 6 show that there were no statistically significant differences between the teachers' attitudes toward e-learning and the availability of computer labs (i.e., available or not available). This result is consistent with the teachers' reflections that not all Saudi schools are equipped with computer labs or the Internet, and when computer labs are available, they may not be equipped to accommodate e-learning approaches to teaching. Table 6

Correlation with Lab Availability

\begin{tabular}{|l|l|l|l|l|}
\hline Item & $N$ & $\begin{array}{l}\text { Pearson Correlation Coefficient of Lab } \\
\text { Availability }\end{array}$ & $p$-value & Conclusion \\
\hline $\begin{array}{l}\text { Total score of } \\
\text { response to } \\
\text { the scale } \\
\text { items }\end{array}$ & 62 & -.17 & .20 & No \\
statistically \\
significant \\
differences
\end{tabular}




\section{CHAPTER 5}

\section{SUMMARY, CONCLUSIONS, RECOMMENDATIONS}

This chapter presents a brief summary of the purpose, research questions, and results of the study. Conclusions, recommendations for practice, and recommendations for future research are also presented. The educational leaders of Saudi Arabia have become attentive to the quality of education in their nation. Improving the quality of education has become a focal point for Saudi planners and educators. E-learning has been a recent focal point in the attempt to improve student learning and to make education accessible to all citizens.

This study was designed to examine the attitudes of high school female math teachers toward the use of e-learning in teaching mathematics in selected high schools in Tabuk, Saudi Arabia. Also, the study examined the extent to which e-learning had been adopted in high schools. Finally, the study examined the results to determine if there were any statistically significant differences in female math teachers' attitudes toward e-learning based on the variables of academic degree, years of experience, IT training courses, and computer lab availability.

The total sample for this study was 70 teachers selected randomly from the total population of female math teachers in the secondary schools of Tabuk, Saudi Arabia. The researcher developed a 5-point Likert scale questionnaire to collect data on teachers' attitudes toward the use of e-learning in education. There were 62 questionnaires returned out of the sample of 70. Descriptive statistics were used to analyze much of the data generated from the questionnaire. Means, standard deviations, ranges, frequencies, percentages, and diagrams were used to analyze and compile the data. A $t$-test was used to test for statistically significant 
differences for the variables of academic degree, years of experience, IT training courses, and computer lab availability.

An examination of the variables revealed that $77 \%$ of the teachers in the sample had 10 years of teaching or less. In terms of academic degree, 61 of the teachers held a bachelors and only one had a masters. The sample was fairly evenly split in terms of those who had computer training (46.8\%) and those who had not received computer training (45.2\%). Over $80 \%$ of the sample reported that they had computer labs available for instruction.

\section{Results of the Study}

The analysis of the responses to the questionnaire revealed that the female high school math teachers' attitudes toward the use of e-learning were highly positive. The mean responses to the questionnaire items revealed that the teachers believed that e-learning enriched the educational process. Their attitudes concerning the use of e-learning in teaching math revealed that they felt e-learning not only made teaching more effective and more interesting, but also enhanced and improved the quality of teaching. The teachers said that e-learning helped them organize their work, improved their performance level in teaching, and helped them in teaching high school math. Overall, the teachers expressed enthusiasm for using e-learning and felt confident and comfortable with the technology. These findings are consistent with results of previous studies on teacher attitudes toward the use of e-learning (Abuaraad \& Faseel, 2006; Almohyssin, 2006).

The female math teachers were highly positive in their beliefs that the use of e-learning in teaching high school math supported the goals and aims of education and improved student learning. The point has already been made that $87 \%$ of the teachers agreed that the educational process can be enriched through the use of e-learning. There was general agreement that the use 
of e-learning in teaching helped the teachers meet the individual differences of the learners. The high percentages reported for questionnaire items 3, 4, 20, 24, and 25 indicate that female high school math teachers held a positive attitude for the role that e-learning can play in improving math education. These findings are consistent with those of previous research concluding that elearning can be effective in improving the quality of teaching and in improving student academic achievement (Alali, 1996; Alhasnawi, 2007; Aljurf, 2006; Bader, 2001).

This study also asked whether there were any statistically significant differences in attitudes toward the use of e-learning reported by the female math teachers and the variables of academic degree, years of teaching experience, computer course (IT) training, and the availability of computer labs. There were no significant differences found when the teachers' attitudes toward e-learning were examined on the variables of academic degree, years of teaching experience, computer course training, and computer lab availability.

\section{Conclusions}

The analysis of the results of this study shows that the subjects hold a highly positive attitude toward the use of e-learning in education. In this researcher's opinion, this highly positive attitude is the result of the extent of teachers' awareness of the importance of e-learning in moving education forward with modern technology and freeing it from the traditional, outmoded methods. This view toward the use of modern technology in education is consistent with previous studies (Abuaraad \& Faseel, 2006; Almohyssin, 2002, 2006).

This study revealed that there is a shortage of courses and programs to train teachers to use the computer in instruction. In this study, $46.8 \%$ of the subjects received training on how to use the computer and its accompanying programs in instruction, whereas $45.2 \%$ did not receive training. This study revealed that almost all teachers have the same attitudes toward e-learning 
regardless of whether they had received training or not. This result may be due to the fact that no in-service training courses were offered to the teachers in the use of e-learning. This finding is consistent with other studies reporting that one of the most important obstacles to the use of elearning is the lack of training teachers receive in using the computer in teaching and learning. These studies recommend that training for teachers be increased (Almohyssin, 2002; Almoussa, 2002; Khuleif, 2001; Zein Aldein, 2006).

The lack of computer labs was a problem for some teachers and for some of the schools in the study. Previous studies have examined the availability of computer labs and the number of computers available for teacher and student use. These studies report that there is a deficiency in the number of computer labs and in the number of computers available for students (Almohyssin, 2002; Doami \& Alshannaq, 2006; Zein Aldein, 2006).

During visits to the Tabuk high schools for girls to distribute the questionnaires, the researcher noticed that there was a shortage of computers for use by students and teachers. This is a recurrent problem that is reported in the literature.

There were no statistically significant differences in teachers' attitudes toward the use of e-learning when examined on the variables of academic degree, years of teaching experience, computer course training, and lab availability. This finding can be easily accounted for when examining the results by academic degree. All but one teacher held a bachelors degree. Therefore, meaningful comparisons could not be made for the variable of academic degree. That there were no significant differences in attitudes when examined by years of experience is somewhat surprising. About $25 \%$ of the sample had 11 or more years teaching experience. About half of the sample had between 6 and 10 years of experience. The remaining sample had 5 years or less experience as a teacher. It was expected that there would be a 
significant difference when compared by years of experience because of the range of experience represented in the sample. This did not occur. E-learning is a relatively new experience for female teachers in Saudi Arabia, and this may account for the lack of significant differences when examined for years of experience as a teacher.

The results of this study indicate that the vast majority of teachers included in the sample held highly positive attitudes toward the use of e-learning in teaching math. They saw it as enriching the educational process, improving the quality of instruction within the class, increasing the level of student achievement, and developing student ability to think. This highly positive attitude toward e-learning across the entire sample provides a strong base of support for expanding the use of e-learning in teaching math or any other subject. The enthusiasm for this methodology is present among teachers and could easily be tapped through planned programs and resource support for the adoption and use of e-learning. The findings of this study are consistent with previous studies (Alali, 1996; Alhasnawi, 2007; Aljurf, 2006; Bader, 2001).

Most subjects included in the study reported that more support from the educational administration was essential for e-learning to be used in teaching. They felt they need intensive training programs on e-learning for teachers and administrators. Schools should be provided with enough computers and accessories to make e-learning accessible for teachers and students. A most important demonstration of support for e-learning would be to connect the school to the Internet.

\section{Recommendations for Practice}

The following is a summary of the recommendations proposed on the basis of the findings presented in this research study. 
1). It is important to promote professional development activities for both teachers and administrators in the use of e-learning in teaching math and other subjects in the schools in Saudi Arabia. These professional development opportunities should include instruction in the technology of e-learning, workshops in the pedagogy of online instruction, and training in the use of the computer in instruction.

2). The logistics and infrastructure need to be improved in the public schools of Tabuk, Saudi Arabia. Schools need to provide students and teachers with enough computers and encourage them to use these tools in their daily educational activities. Connection to the Internet is essential as is having the computers and software necessary for effective implementation of e-learning into the curriculum.

3). Teacher training should focus on how to integrate new technologies and methodologies into their teaching. Teachers should be encouraged to diversify their teaching strategies by using e-learning to promote inquiry, problem solving, and critical thinking among their students.

4). In-service training is needed on the process of developing electronic materials and on using new software in teaching. E-learning is just a medium for teaching and learning, and the materials that make it effective must be developed by the teacher. Students often can be involved in the development of material to be used with e-learning.

5). The Ministry of Education should promote the use of e-learning in the teaching and learning process. Teachers included in this study felt that e-learning helped to improve the quality of the educational experience for students, assisted them in meeting the individual needs of students, and was instrumental in developing the ability to think among students. 
6). Computer labs should be made available for all students and teachers. The lack of access to computer labs is a barrier to the adoption and incorporation of e-learning into the teaching and learning process. Having adequate computer labs would enhance the educational opportunities for all students in all subjects.

7). It is important to incorporate e-learning into the teaching of math. Mathematics is a study of patterns, and e-learning and the use of the computer provide opportunities for students to explore these relationships in an online global environment. This would open up the educational process far beyond that contained in a single textbook.

\section{Recommendations for Future Research}

The present study used a survey designed to provide information regarding female math teachers' attitudes toward the use of e-learning in teaching math. Though survey research is important, it does not provide insight into best practices in the teaching of math. Therefore, the researcher suggests the following topics for further investigation.

1). Research should be conducted on the impact of e-learning on students' comprehension of mathematical concepts. This research should be conducted at all educational levels in Saudi Arabia and should include male and female students as part of the investigation.

2). Research should be conducted on the impact of e-learning on the development of creative thinking abilities in high school students in Saudi Arabia. The development of creative thinking among students is one of the most often stated goals of education. This research could provide evaluative data as to the effectiveness of e-learning in reaching this goal. 
3). Research conducted on the effect of e-learning on mathematical problem solving abilities would provide valuable information for curriculum development and the teaching of math. The ability to apply problem solving skills in math has been a frequently reported problem in research on student learning. This research could provide valuable information for improving instruction in math. A similar study must be done for all academic subjects.

4). Qualitative research should be conducted to determine what influences some teachers to integrate e-learning into their teaching while other teachers are hesitant to use elearning. This research could aid educational planners in the process of developing plans to incorporate e-learning in mathematics and other subjects.

5). Studies similar to the ones mentioned above could be conducted at the elementary and middle school levels. This research would provide a compendium of research on the impact of the use of e-learning across all levels of education. 


\section{REFERENCES}

Alhaamed, M., Abdulqader, M., Alotiybi, B., \& Metulee, N. (2007). Education in Saudi Arabia: To see the present and look to the future. Riyadh: Alrushd Nasheroon.

Abdulkareem, M. (2009). The reality of the use of e-learning in kingdom schools in Riyadh. Retrieved from http://www.abegs.org

Abuaraad, S. B., \& Faseel, A. M. (2006). The use of computers by teaching staff in teachers' colleges - Saudi Arabia. Saudi Journal of Education and Psychology GESTEN, King Saud University, 26(195), 243-298.

Afaneh, M. (2006). E-learning concepts and techniques. Retrieved from http://iit.bloomu.edu/Spring2006_eBook_files/ebook_spring2006.pdf

Ajarma, M. (2007). E-learning in higher education: Adopting, adapting and applying (3A eLearning methodology) (Master's thesis). University of Northern Virginia. Retrieved from http://www.thesisabstracts.com/ThesisAbstract_259_eLearning-in-HigherEducation-Adopting-Adapting-and-Applying-(3A-eLearning-Methodology).html

Al Makoshi, A. A. (2001). The psychological bases to learn and educate the mathematics styles and contemporary theories. Riyadh: King Fahd's National Library.

Alabbadi, M. (2002). The electronic education and the traditional education what it is the difference. Al-Marifa Magazine, 36(91), 18-32.

Alali, I. A. (1996). The effectiveness of the education with the computer's aid of a study semi experimental for the education of the mathematics subject to the primary fifth grade pupils. Retrieved from www.aghandoura.com/PHD/USE.htm

Alaqeel, A. (2005). Education policy and its regime in Saudi Arabia. Riyadh: Alrushd Nasheroon. 
Alattarji, A. M. (2002, October 22-23). Experimental hypothetical Internet e-school. Retrieved from http://colleges.ksu.edu.sa/Arabic\%20Colleges/CollegeOfEducation/DocLib23/Forms/AllI tems.aspx

Alfleih, K. (2004). The electronic education. Retrieved from http://www.jedu.gov.sa/

Alhadi, M. (2005). The electronic education through the Internet. Cairo: The Lebanese Egyptian Press House.

Alhajji, N. (2003). The reality of e-learning in Jordanian universities. Jordan: Arab Bureau of Education for the Gulf States. Retrieved from http://webcache.googleusercontent.com/search?q=cache:k9Brh6NzI0sJ:www.abegs.org/s ites/Upload/DocLib3

Alharbi, M. B. (2006). The demands of the use of the electronic education are to teach the mathematics by the secondary stage from the viewpoint of practitioners and specialists [Web log post]. Retrieved from http://drkhaledomran.blogspot.com/2009_09_01_archive.html

Al-Hareky, S. M. (1983). A study of the effectiveness of modern educational technology on the mathematics performance of elementary students in Saudi Arabia (Doctoral dissertation). The Pennsylvania State University. Retrieved from http://search.proquest.com/docview/303171820?accountid $=2837$

Alhasnawi, M. A. (2007). The effects of using e-learning techniques in teaching the basics of electronics on students' academic achievement and developing their scientific thinking. Journal of Human Sciences, 5(35). Retrieved from http://www.ulum.nl/c89.html 
Aljurf, R. S. (2006). The effectiveness of e-learning in teaching English language in the university stage-Saudi Arabia. Retrieved from http://faculty.ksu.edu.sa/aljarf/arabiccv/Pages/presentations.aspx

Al-Khashab, H. (2007, July 15). Attitude toward e-learning an empirical study in Kuwait [Online post]. Retrieved from http://www.scribd.com/doc/2931290/Attitude-towards-Elearning

Alkhezzi, F. A. (2002, October). Internet use of graduate and undergraduate students in the College of Education at Kuwait University. Retrieved from http://search.proquest.com.www.libproxy.wvu.edu

Almallah, M. (2010). E-schools, and the role of Internet in education. Amman: Dar Althaqafah. Almohyssin, I. A. (2002). E-learning: Luxury or necessity? Retrieved from http://colleges.ksu.edu.sa/Arabic\%20Colleges/CollegeOfEducation/DocLib23/Forms/AllI $\underline{\text { tems.aspx }}$

Almohyssin, I. A. (2006). The status and obstacles of adopting computers at colleges of education-Saudi universities. The Journal of Education-University of Kuwait, 15, 57.

Almoussa, A. b.-A. (2002, August). The electronic learning: Its concept, its features, its benefits and its obstacles. Paper presented at the Future School Seminar. Abstract retrieved from hpp://www.ksu.edu.sa/seminars/Futureschool/Abstracts/AlmosaAbstract.htm

Almubirik, H. (2005). The electronic learning and development of teaching way in the university with the use of the electronic education with a suggested model. Paper presented at the Future School Seminar. Riyadh: King Saud University. Retrieved from www.ksu.edu.sa/seminars/futureschool,10-12-2005

Aloraini, S. (2005). Distant education. Riyadh: King Fahd's National library. 
Alotaibi, N. (2006, December 18). The technology of the information. Riyadh Newspaper, Issue 14056. Retrieved from http://www.alriyadh.com/

Alradadi, A. (2007). Attitude of teachers and supervisors about their use of e-learning in teaching mathematics in middle school. Retrieved from http://libback.uqu.edu.sa/ipac20

Al-Shabi, M. (2013). UML modeling for general educational services in KSA integrated with GIS. IJCSI International Journal of Computer Science Issues, 10(2), No. 3, 272-279. Retrieved from http://www.ijcsi.org/papers/IJCSI-10-2-3-272-279.pdf

Alsufeani, M. (2008). Importance and use of e-learning in teaching high school mathematics from the perspective of teachers. Retrieved from http://lrc-online.net/library/wpcontent/uploads/2010/07/5490.pdf

Alsunbol, A., Alkhateeb, M., Metwalli, M., \& Abduljawad, N. A. (2004). The educational system in the kingdom of Saudi Arabia. Riyadh: Dar Al Khariji for Publishing and Distribution.

Altawdri, A. (2004). Electronic school and new role for teacher. Riyadh: Alrushed Publishers. Alwidanee, M. Y. (2009). The reality of the use of educational technology and teaching laboratory aids in the teaching of mathematics at primary schools. Retrieved from http://libback.uqu.edu.sa/hipres/ABS/ind7370.pdf

Alzahrani, A., \& Yamani, H. A. (2008). A future view for the electronic education in the Saudi higher education organizations. Retrieved from www.kau.edu.sa/dvworkshop/first.asp Alzamil, O. A. (2003). High school social studies teachers' attitudes and usage of instructional technology in Saudi Arabia (Doctoral dissertation). Fayetteville, Arkansas: University of Arkansas. 
Arabasz, P., Pirani, J. A., \& Fawcett, D. (2003). Supporting e-learning in higher education. Retrieved from http://net.educause.edu/ir/library/pdf/ers0303/rs/ers0303w.pdf

Arkin, E. (2003). Teachers' attitudes toward computer technology use in vocabulary instruction. Retrieved from http://www.thesis.bilkent.edu.tr/0002298.pdf

Bader, B. (2007). Foundation of teaching mathematics. Jeddah: Dar Kunuze Almaarifah, Saudi Arabia.

Bader, M. (2001). The use of Internet in teaching unit of statistics for middle school students. The Thirteenth Scientific Conference: The Curricula, Cognitive and Technological Contemporary Revolution (pp. 171-192). Cairo: Dar al Eiafah - Ain Shams University.

Becker, H. J. (1985). How schools use microcomputers: Results from a national survey. In M. Chen \& W. Paisley (Eds.), Children and microcomputers: Research on the newest medium (pp. 87-107). Beverly Hills, CA: Sage.

Berkowitz, R. J. (2000). Effects of in-service training on the technology practices and attitudes of physical education teachers (Doctoral dissertation). The Ohio State University.

Birisci, S., Metin, M., \& Karakas, M. (2009). Determining prospective elementary teachers' attitudes toward computer: A sample from Turkey1. Bulgarian Journal of Science and Education Policy (BJSEP), 3(1), 109-127. Retrieved from http://bjsep.org/getfile.php?id=55

Davenport, M. K. (2000). Factors related to the Tennessee K-12 educators' implementation of the Internet into classroom activities and professional development (Doctoral dissertation). East Tennessee State University. 
Doami, H., \& Alshannaq, Q. (2006, March 27-29). The obstacles of the electronic learning in the Jordanian secondary schools from the viewpoint of teachers and students. The International Conference of the Distant Education, Masqat.

Doami, H., \& Alshannaq, Q. (2010). Attitude of teachers and students to use e-learning in secondary schools of Jordan. Journal of the University of Damascus, 1-2(26), 235-271. Retrieved from http://www.damascusuniversity.edu.sy/mag/edu/images/stories/235$\underline{271 . p d f}$

E-learning. (2010). About e-learning. Retrieved from http://www.aboutelearning.com/definition-of-e-learning.html

E-learning. (2004). Introduction to e-learning. Retrieved from http://www.chengzhi.net/english/index.htm

Fraenkel, J. R., \& Wallen, N. E. (1990). How to design and evaluate research in education. New York, NY: McGraw-Hill.

Foster, J. (1998). Data analysis using SPSS for Windows. San Francisco, CA: Sage.

Falvo, D. (1999). A qualitative study of five West Virginia K-12 RuralNet project teachers merging the Internet into their instruction and how the Internet affects professional practice (Doctoral dissertation). Morgantown, WV: West Virginia University.

Garofalo, J., Drier, H., Harper, S., Timmerman, M. A., \& Shockey, T. (2000). Promoting appropriate uses of technology in mathematics teacher preparation. Contemporary Issues in Technology and Teacher Education, 1(1), 68-88. Retrieved from http://ebookbrowse.com/garofalo-promoting-appropriate-uses-of-technology-in$\underline{\text { mathematics-teacher-preparation-pdf-d473573269 }}$ 
Gerber, S., \& Shuell, T. J. (1998). Using the Internet to learn mathematics. Journal of Computers in Mathematics and Science Teaching, 17(2/3), 113-132.

Humaisat, H. (1989). A survey study on the use of computers in Jordanian schools. The New Education, 46(1), 71-85.

Karatas, I. (2011, March 10). Experiences of student mathematics teachers in computers-based mathematics learning environment. International Journal for Mathematics Teaching and Learning [only in electronic form], 235-262. Retrieved from http://www.cimt.plymouth.ac.uk/journal/karatas.pdf

Khan, B. (2005). The strategies of the electronic learning. Halab: Shuaa for Publication and Science.

Khan, B. H. (1999). Web-based instruction. Englewoods Cliffs, NJ: Educational Technology Publications Inc.

Khuleif, Z. N. (2001, May). The computer and its appendicies in the preparation of the educational methods. Paper presented at the Educational Process Conference in the Age of the Internet, An-Najah National University, Nablus, Palestine. Retrieved from http://www.minshawi.com/other/Khlaif.htm

Lal, Z. Y., \& Aljundi, A. (2005). Electronic communication and technology of learning (3rd ed.). Riyadh: Alobikan Library.

Lundin, R. (1993). Overseas experience in non-traditional modes of delivery in higher education using state-of-the-art technologies: Best practice. Canberra: Australian Government Printing Service.

Marcolini Hoover, M. L. (2003). Effects of the West Virginia K-12 RuralNet Project on elementary school teachers' instructional practices (Doctoral dissertation). Morgantown, 
WV: West Virginia University. Retrieved from

http://firstsearch.oclc.org.www.libproxy.wvu.edu/WebZ/FSPage?pagetype=return_frame set:sessionid=fsapp5-40701-hiszkkwy-

iteba1:entitypagenum=2:0:entityframedurl $=\mathrm{http} \% 3 \mathrm{~A} \% 2 \mathrm{~F} \% 2 \mathrm{Fhdl}$.handle.net $\% 2 \mathrm{~F} 10450 \%$ $\underline{\text { 2F2777:entityframedtitle }=\text { WorldCat:entityframedtimeout }=30: \text { entityopenTitle }=: \text { entityopen }}$ Author=:entityopenNumber $=$ :

Marcum, C. E. (2010). Teacher and administrator perceptions of technology use in two West Virginia middle schools (Doctoral dissertation). Morgantown, WV: West Virginia University. Retrieved from http://p8881wvuscholar.wvu.edu.www.libproxy.wvu.edu//exlibris/dtl/d3 1/apache media/L2V4bGlic mlzL2R0bC9kM18xL2FwYWNoZV9tZWRpYS8yNDE1Mg==.pdf

Mehmet, O. A. (2005). Mathematics teachers' attitudes toward computers. The Turkish Online Journal of Educational Technology, 4(3), 82-88.

MoE-SA, W. (2011). Ministry of Education in Saudi Arabia. Retrieved from http://www.moe.gov.sa

Ministry of Economy and Planning, UN Team, UNDP. (2010). Kingdom of Saudi Arabia Millennium Development Goals Report 2010. Riyadh.

Mohammad, M. H. (2004). New trends in education of mathematics, studies and researches. Cairo: The Books World.

National Council of Teachers of Mathematics (NCTM). (2000). Principles and standards for school mathematics. Reston, VA: NCTM.

National Research Council. (2000). How people learn: Brain, mind, experience, and school. Washington, DC: National Academy Press. 
Niculescu-Aron, G. I., Asandului, L., Mazurencu, M. M., \& Mihaescu, C. (2007). A cram of elearning advantages and disadvantages. Informatica Economică, 42(2). Abstract retrieved from http://papers.ssrn.com/sol3/papers.cfm?abstract id=1132103

Norusis, M. J. (1999). SPSS 9.0 guide to data analysis. Upper Saddle River, NJ: Prentice Hall Inc.

Rosenberg, M. J. (2001). E-learning: Strategies for delivering knowledge in the digital age. New York: McGraw-Hill. Retrieved from http://nwlink.com/ Donclark/hrd/elearning/define.html

Saadah, J. A., \& Alsartawi, F. A. (2004). The use of computer and Internet in the fields of upbringing and education. Muscat: Dar Al-Shorok.

Salamah, A., \& Abu-Raya, M. (2002). Al-hasoob fi Al-taaleem 'Computers in Education.' Jordan: Alahlia.

Salem, A. (2004). Technology of the education and the electronic education. Riyadh: Alrushed Publishing Press.

Sandholtz, J. H., Ringstaff, C., \& Dwyer, D. C. (1994). Student engagement revisited: Views from technology-rich classrooms. Cupertino, CA: Apple Computer.

Shamatha, J. H., Peressini, D., \& Meymaris, K. (2004). Technology-supported mathematics activities situated within an effective learning environment theoretical framework. Contemporary Issues in Technology and Teacher Education, 3(4), 362-381. Retrieved from http://www.citejournal.org/articles/v3i4mathematics1.pdf

Sorensen, E. K., Mathiasen, H., \& Dalsgaard, C. (2009, June 10-12). E-learning concepts in higher education. Paper presented at ICELW 2009 The International Conference on ELearning in the Workplace, New York. Retrieved from 
http://nordicom.statsbiblioteket.dk/ncom/files/178235/Sorensen_Mathiasen_Dalsgaard_E -learning_concepts.pdf

Stockley, D. (2003). E-learning definition and explanation. Retrieved from http://derekstockley.com.au/elearning-definition.html

Uys, P. M. (2000, April). Toward the virtual class: Key managment issues in tertiary education (Doctoral dissertation). Wellington, New Zealand: Victoria University of Wellington. Retrieved from http://www.globe-online.com/philip.uys/thesisphilipuys2000.pdf

U.S. Department of Education, Office of the Under Secretary, Planning and Evaluation Service. (1999). Designing effective professional development: Lessons from the Eisenhower program. Washington, D.C.

Wiest, L. R. (2001). The role of computers in mathematics teaching and learning. In D. J. Tooke \& N. Handerson (Eds.), Using information technology in mathematics education (pp. 4155). Binghampton, NY: Haworth Press.

Zein Aldein, M. M. (2006, April). The effect of the experience of the electronic education in the Egyptian preparatory schools on the academic collection to the students and their trends towards this experience. The Second Scientific Conference of the College of Specific Education. Qanat Al-Suez University, Egypt. 
APPENDICES 
Appendix A

English Version of the Survey:

A Questionnaire of Female Teachers' Attitudes toward Adopting E-Learning in Teaching Math 


\section{Appendix A}

\section{English Version of the Survey}

A Questionnaire of Female Teachers' Attitudes toward Adopting E-Learning in Teaching Math

The purpose of this questionnaire is to investigate female high school math teachers' attitudes towards using e-learning to teach math in the Tabuk educational district of Saudi Arabia. The questionnaire also examines their use of the computer and the Internet in teaching math.

\section{Dear responder:}

I appreciate your interest in participating in this questionnaire. Your response is very important and all data obtained will be used for the purpose of this research and will remain confidential. If you feel that you cannot answer any of these questions, please leave them blank. Your participation in this study is entirely voluntary. Thank you for your support in this study.

\section{Part A: Personal information}

Please check the answer below that best describes your situation:

- Teaching experience:
a). 0-5 years
b). 6-10 years
c). 11-15 years
d). 16 years or more

- Education level:
a. Diploma
b. Bachelor
c. High Diploma
d. Master
e. Doctorate
f. Other (please indicate.....) 


\section{Part B: Teachers' attitudes toward e-learning}

Below is a series of statements. There is no right or wrong answer and your response to the items should reflect the extent to which the idea expressed is true or not true for you. Please check the designation that most closely reflects your attitude.

\begin{tabular}{|c|c|c|c|c|c|c|}
\hline No & Item & \begin{tabular}{|l|l|} 
Strongly \\
Disagree
\end{tabular} & Disagree & Uncertain & Agree & $\begin{array}{l}\text { Strongly } \\
\text { Agree }\end{array}$ \\
\hline & $\begin{array}{l}\text { I prefer using e-learning to } \\
\text { teach math classes }\end{array}$ & & & & & \\
\hline & $\begin{array}{l}\text { I feel uncomfortable towards } \\
\text { using e-learning in teaching }\end{array}$ & & & & & \\
\hline & $\begin{array}{l}\text { Using e-learning to teach math } \\
\text { is very helpful to me }\end{array}$ & & & & & \\
\hline & $\begin{array}{l}\text { I could do my math work more } \\
\text { effectively with e-learning }\end{array}$ & & & & & \\
\hline & $\begin{array}{l}\text { Learning math with e-learning } \\
\text { is a waste of students' time }\end{array}$ & & & & & \\
\hline & $\begin{array}{l}\text { I can't think of any way that I } \\
\text { might use e-learning in my } \\
\text { class }\end{array}$ & & & & & \\
\hline & $\begin{array}{l}\text { Using e-learning in teaching } \\
\text { my classes helps organize my } \\
\text { work }\end{array}$ & & & & & \\
\hline & $\begin{array}{l}\text { I prefer using the text book and } \\
\text { the chalk board rather than } \\
\text { using e-learning }\end{array}$ & & & & & \\
\hline & $\begin{array}{l}\text { Using e-learning to teach math } \\
\text { is challenging me to be a better } \\
\text { teacher }\end{array}$ & & & & & \\
\hline & $\begin{array}{l}\text { Using e-learning to teach my } \\
\text { classes will make me feel } \\
\text { comfortable }\end{array}$ & & & & & \\
\hline & $\begin{array}{l}\text { Using e-learning to teach math } \\
\text { makes teaching hard for me }\end{array}$ & & & & & \\
\hline & $\begin{array}{l}\text { Working with e-learning inside } \\
\text { my classroom would be } \\
\text { enjoyable }\end{array}$ & & & & & \\
\hline & $\begin{array}{l}\text { E-learning is not the most } \\
\text { effective teaching method in } \\
\text { the classroom }\end{array}$ & & & & & \\
\hline & $\begin{array}{l}\text { It would bother me if I have to } \\
\text { use e-learning in my math } \\
\text { classes }\end{array}$ & & & & & \\
\hline
\end{tabular}




\begin{tabular}{|c|}
\hline $\begin{array}{l}\text { E-learning is a useful tool for } \\
\text { improving my teaching. }\end{array}$ \\
\hline $\begin{array}{l}\text { I prefer to teach using e- } \\
\text { learning rather than in the } \\
\text { traditional way. }\end{array}$ \\
\hline $\begin{array}{l}\text { I never support the idea of e- } \\
\text { learning implementation in } \\
\text { math classes }\end{array}$ \\
\hline $\begin{array}{l}\text { I intend to use e-learning to } \\
\text { improve the way I teach }\end{array}$ \\
\hline $\begin{array}{l}\text { E-learning is making teaching } \\
\text { boring for me }\end{array}$ \\
\hline $\begin{array}{l}\text { E-learning never assists } \\
\text { students to learn better }\end{array}$ \\
\hline $\begin{array}{l}\text { The use of e-learning can } \\
\text { improve the quality of } \\
\text { classroom instruction }\end{array}$ \\
\hline $\begin{array}{l}\text { I feel confident to use e- } \\
\text { learning in my classes }\end{array}$ \\
\hline $\begin{array}{l}\text { I do not like to use e-learning } \\
\text { software to teach math }\end{array}$ \\
\hline $\begin{array}{l}\text { Using e-learning in the } \\
\text { classroom will reduce student } \\
\text { learning }\end{array}$ \\
\hline $\begin{array}{l}\text { I am eager to use e-learning in } \\
\text { my math classes }\end{array}$ \\
\hline
\end{tabular}

26. E-learning helps meet individual differences among students.

27. I see that e-learning is a way of enriching the educational process.

\section{Part C: Computer utilization and IT courses training}

1. Do you own (or have direct access to) a personal computer? __ yes __ no (if" yes "please respond to question 2 through 11, if "no" go directly to question 9)

2. How often do you use your computer?

daily ___ weekly __ two times a month__ rarely, if ever

3. Do you use the computer for educational purposes in your teaching? often occasionally rarely almost never

4. If you do use a computer in your school, have you been trained in the use of computers for educational purposes? yes no (if "no "proceed directly to question 6) 
5. Which of the following best describes the source (the provider) of your computer training? self-tutored __ colleagues or friends ___ my school __ my educational district Ministry of Education others (please identify or describe)

6. If you have not received training in the use of the computer for educational purpose, rank, in order of importance, the reasons you lack the necessary training.

(Record 1 in the blank preceding the most important reason for lack of training, 2 preceding the next important factor, and so on).

disinterest, lack of personal initiative. lack of computer hardware in my school. lack of appropriate software in my school. lack of school administrative support. lack of educational district support. lack of ministry of education encouragement and support.

7. Do you have access to the Internet? yes no

8. If yes, do you use the Internet for educational purpose? yes no

9. Do you have a computer lab in your school? yes no

10. If yes, is it accessible to all teachers? yes ___ no (if no, please explain why not.)

11. For those who don't use the computer lab, please rank in order of importance the reason you do not use a computer and Internet in your professional work

(Start from 1, 2, etc.):

lack of personal interest in computer and the Internet. lack of opportunity (time, money, etc.) to learn about computers and the Internet. personal skepticism and doubts about the usefulness of computers and the Internet. other (please explain)

Note: If you would like to add suggestions about using e-learning to teach math, please list them below. 
Appendix B

Arabic Version of the Survey 


\section{Appendix B}

\section{Arabic Version of the Survey}

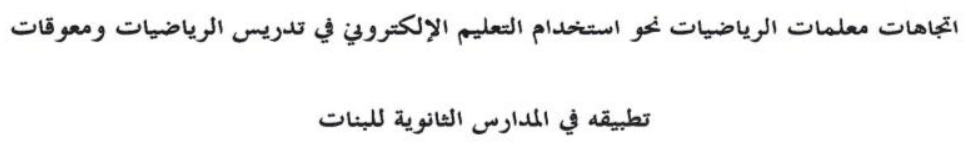

أختك الباحثة

عاتشة محمد خليفة البلوي 


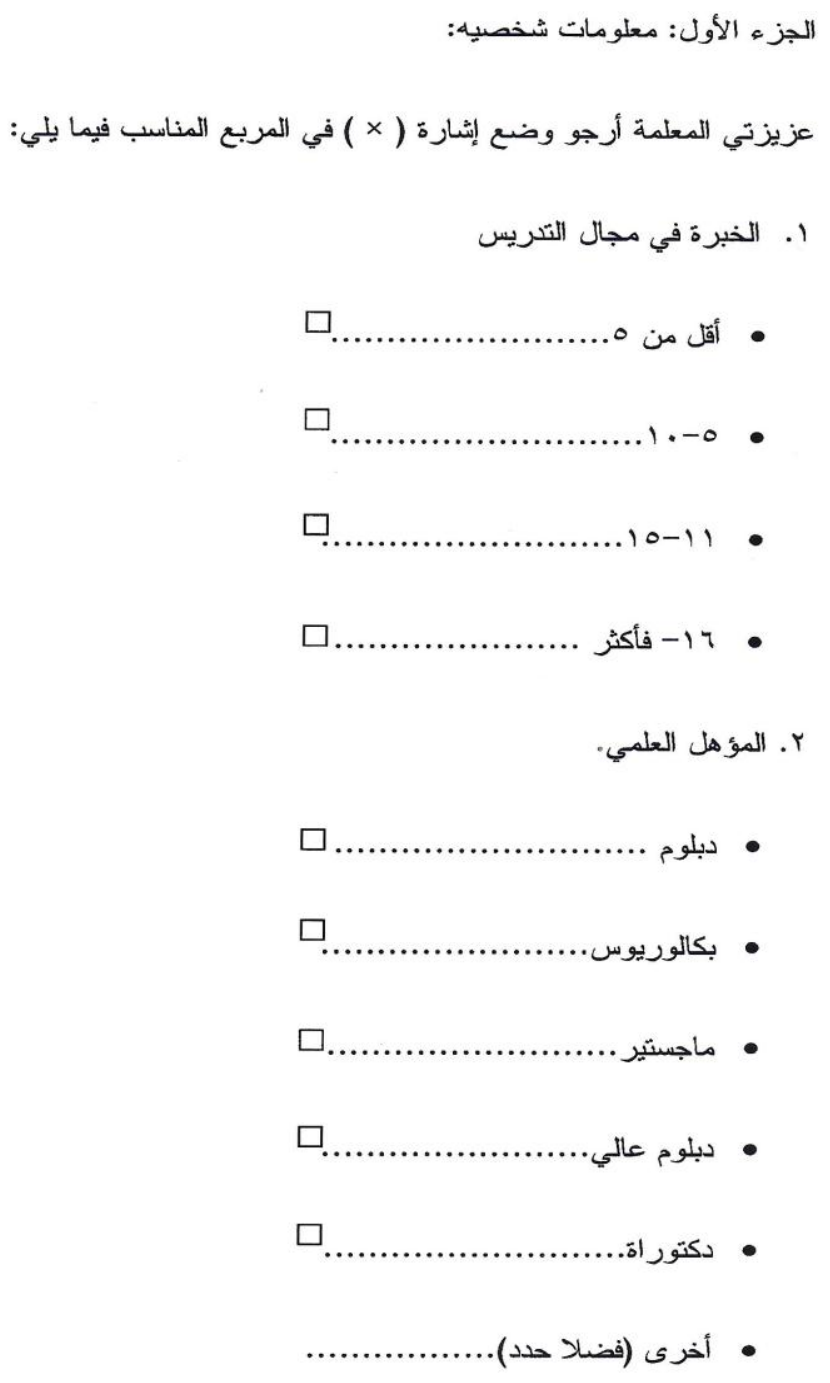




$$
\text { الجزء الثاني: مقياس الاتجاهات نحو استخدام التعليم الالكتروني: }
$$

فيما يلي مجمو عه من العبارات التي تهذف إلى قياس الاتجاه نحو استخدام التعليم الاككتروني

في تدريس الرياضيات. علما انه لا يوجد صح أو خطأ في هذه العبارات. المرجو منك أختي

المعلمة الإجابة على كل فقره بطريقه تعبر عن رأيك ومشاعرك وذلك بوضع إشارة (× ) في

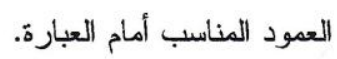

\begin{tabular}{|c|c|c|c|c|c|c|}
\hline ل الو بُدة & أو أوفق & غتأكدة & أو افق & بشدة أواقق & العبارة & P \\
\hline & & & & & الرياضل أستخدام التعليم الاكتروني في تدريس & .1 \\
\hline & & & & & في تدريس الرياضبات. &.$r$ \\
\hline & & & & & في تدريس الرياضئندات النعليم الاككتروني يساعدني كثيرا &.$r$ \\
\hline & & & & & 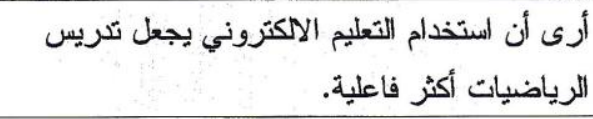 &.$\varepsilon$ \\
\hline & & & & & الرياضى أن استخدام التعليم الاككتروني في تنريس & .0 \\
\hline & & & & & 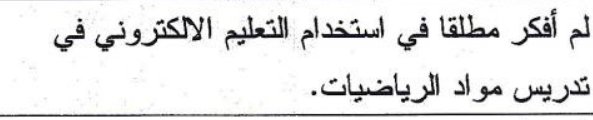 & .1 \\
\hline & & & & & 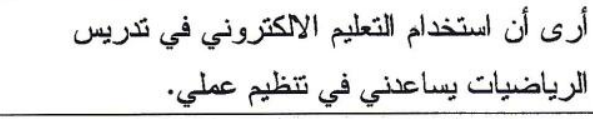 &.$v$ \\
\hline & & & & & 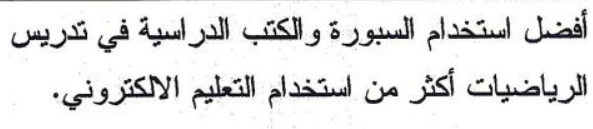 &.$\wedge$ \\
\hline
\end{tabular}




\begin{tabular}{|c|c|c|c|c|c|c|}
\hline لا أو افق & y & غير & أو افق & أو افق & & p \\
\hline \multirow[t]{4}{*}{ |بشدة } & أوفق & متأكدة & & بشدة & العبارة & \\
\hline & & & & & 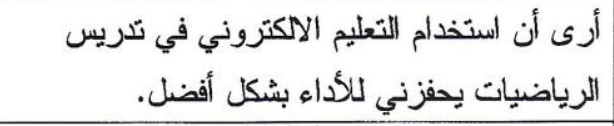 & .9 \\
\hline & & & & & أرى أن التتخدام التعليم الاكتروني في تكريس. & 1. \\
\hline & & & & & 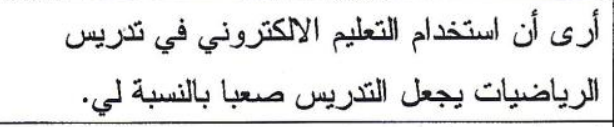 & "1 \\
\hline \multirow[t]{5}{*}{$\frown$} & & & & & 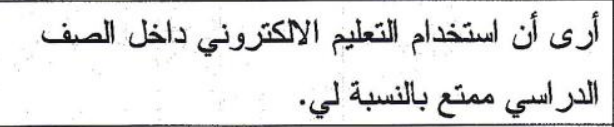 & Ir \\
\hline & & & & & 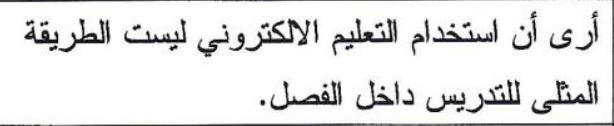 & ir \\
\hline & & & & & 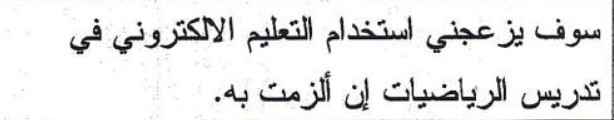 & $1 \&$ \\
\hline & & & & & في أرى أن التعليم الالكتروني أداة مفيدة لتحسين أدائي & 10 \\
\hline & & & & & 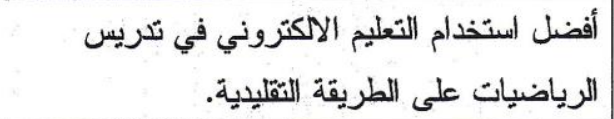 & 14 \\
\hline \multirow[t]{5}{*}{$\frown$} & & & & & |لا أويديد استخدام التعليم الاككتروني في تدريس & iv \\
\hline & & & & & 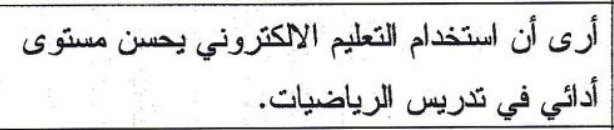 & in \\
\hline & & & & & استخدث الملام التعليم الاكتروني في تدريس الرياضيات & 19 \\
\hline & & & & & 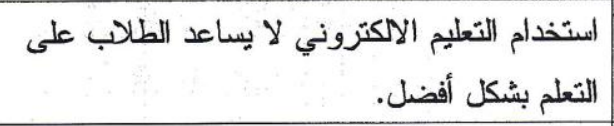 & r. \\
\hline & & & & & 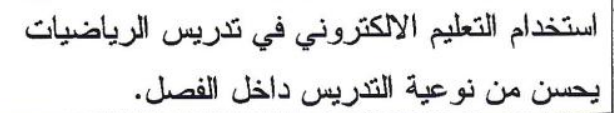 & $r$ \\
\hline
\end{tabular}




\begin{tabular}{|c|c|c|c|c|c|c|}
\hline 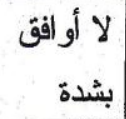 & 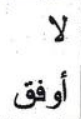 & غتير & أو افق & بشدة أو بق & العبارة & م \\
\hline & & & & & أشعر بالثقة لاستخدام التعليم الاكتروني في تدريس & $r$ \\
\hline & & & & & الا أحبذ استخدام التعليم الاكتروني في تدريس & rit \\
\hline & & & & & 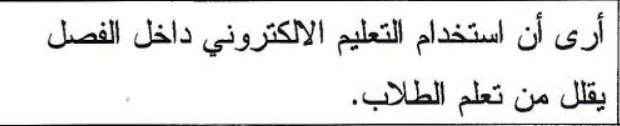 & $\varepsilon$ \\
\hline & & & & & 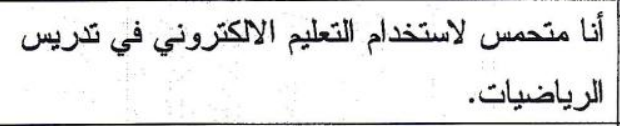 & 10 \\
\hline & & & & & 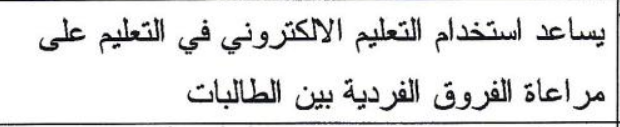 & 4 \\
\hline & & & & & 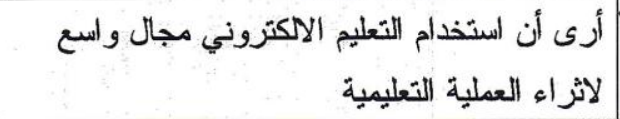 & \\
\hline
\end{tabular}




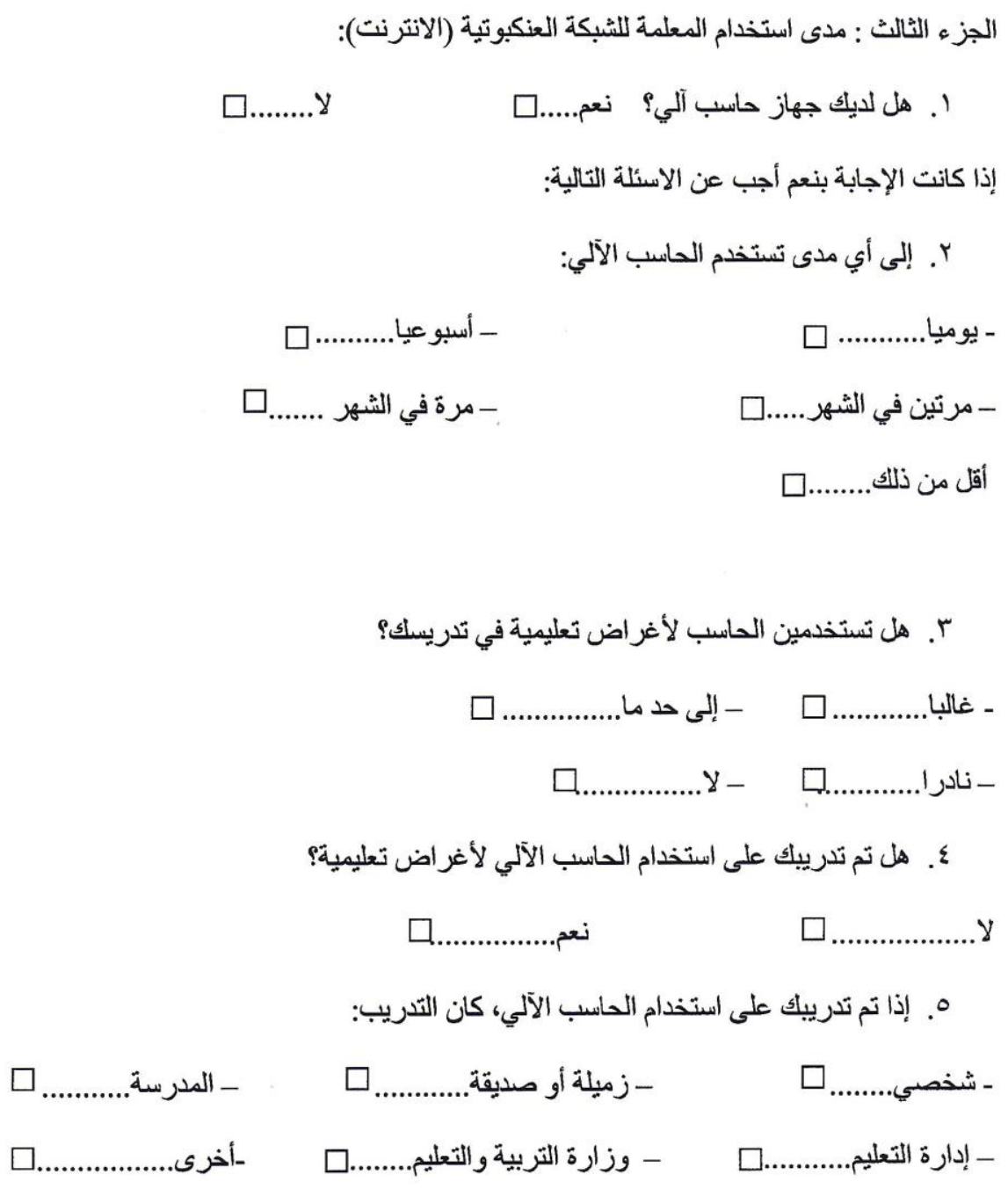




$$
\begin{aligned}
& \text { T. إن لم يكن قد تم تدريبك على استخدام الحاسب الآلي لأغر اض تعليمية، رتبي حسب } \\
& \text { الأولوية والأهمية أسباب عدم التدريب، من. } 1 \text { إلى } 7 \text { : }
\end{aligned}
$$

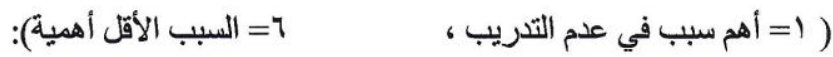

$$
\begin{aligned}
& \text {............. عدم الاهتمام وقلة الدافعية. }
\end{aligned}
$$

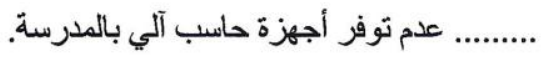

$$
\begin{aligned}
& \text {............ عدم توفر برامج تعليمية للحاسب الآلي بالمدرسة. } \\
& \text {........... عدم توفر الدعم الكافي من إدارة المدرسة. }
\end{aligned}
$$

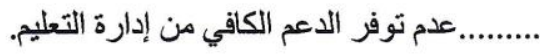

$$
\begin{aligned}
& \text { (ال............... }
\end{aligned}
$$

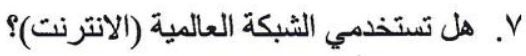

$$
\begin{aligned}
& \square \text {................. } \\
& \text { ن............... }
\end{aligned}
$$

^. إذا كانت الإجابة بنعم: هل تستخدم الشبكة العنكبوتية العالمية لأغر اض تعليمية

$$
\text { (التدريس). }
$$

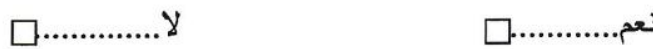

$$
\begin{aligned}
& 9 \text { 9. إذا كانت الاجابة بـ(لا): أجيبي عن الاسئلة التالية بنعم او لا: }
\end{aligned}
$$

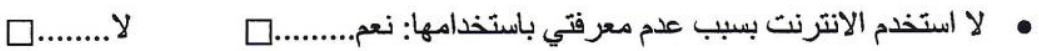

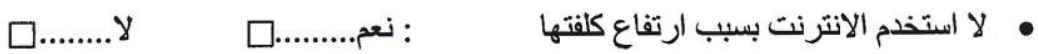

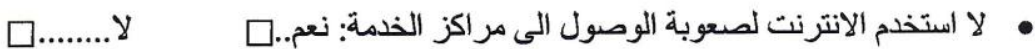

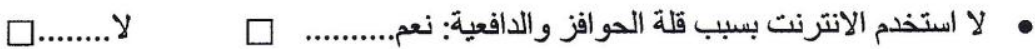



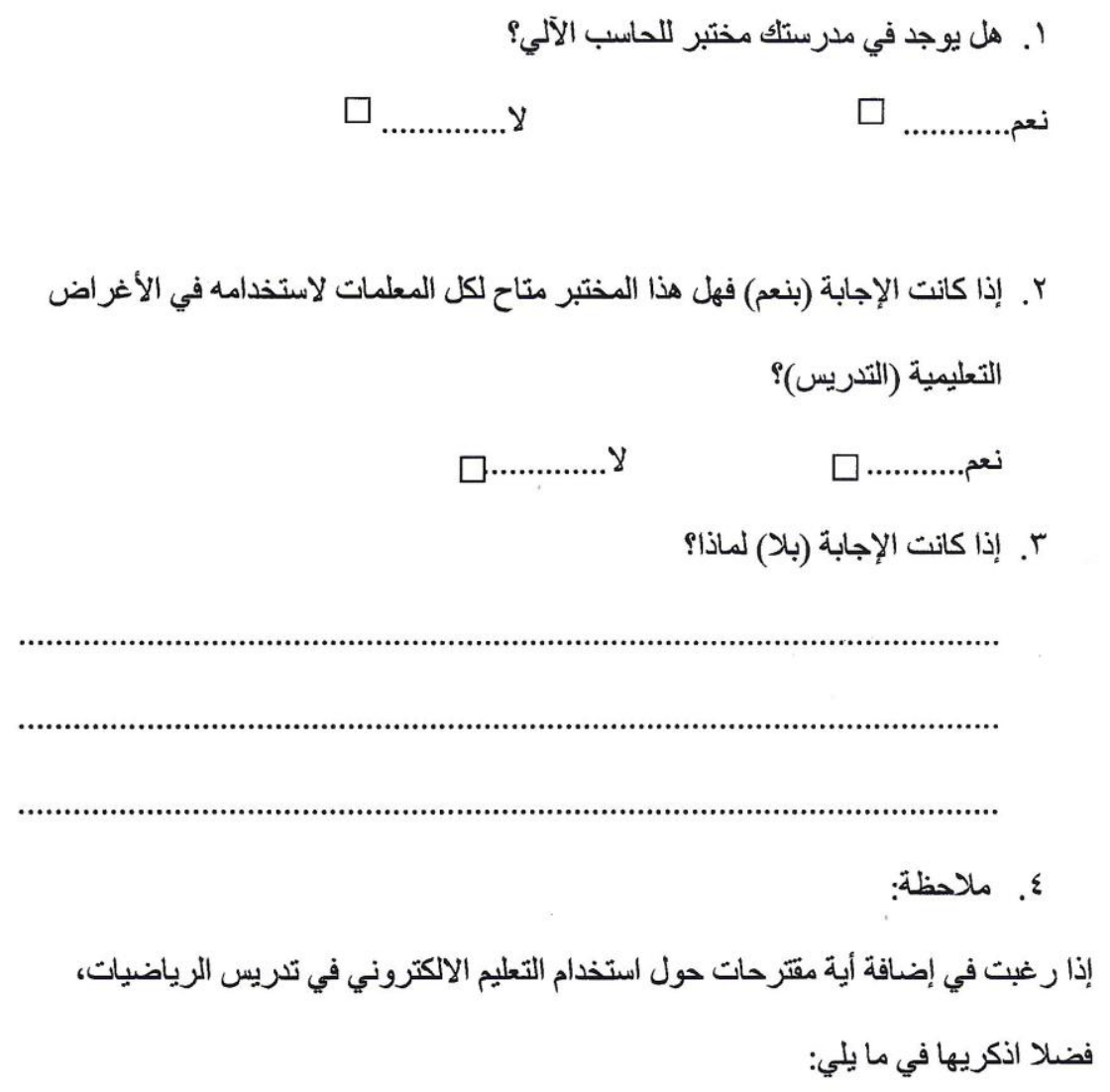

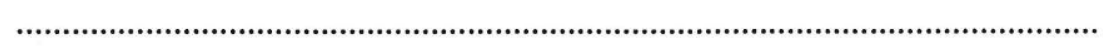

هذا ولكم مني جزيل الثكر والامتنان.

الباحثة / عائشة محمد خليفة البلوي 
Appendix C

Tables 


\section{Appendix C}

Tables

Table 7

Frequencies Tables of Subjects and Percentages for the Study

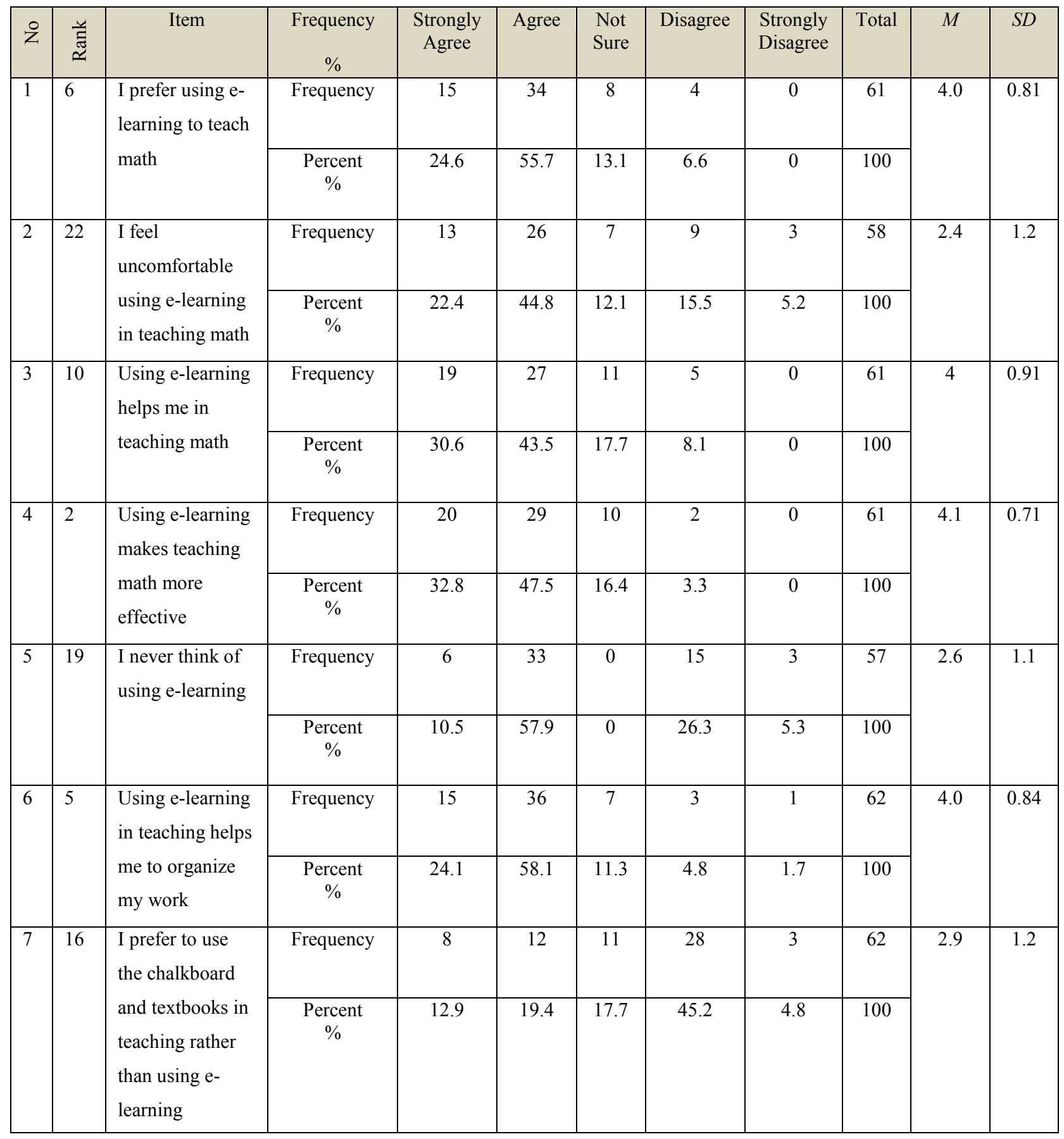


Table 7 (continued)

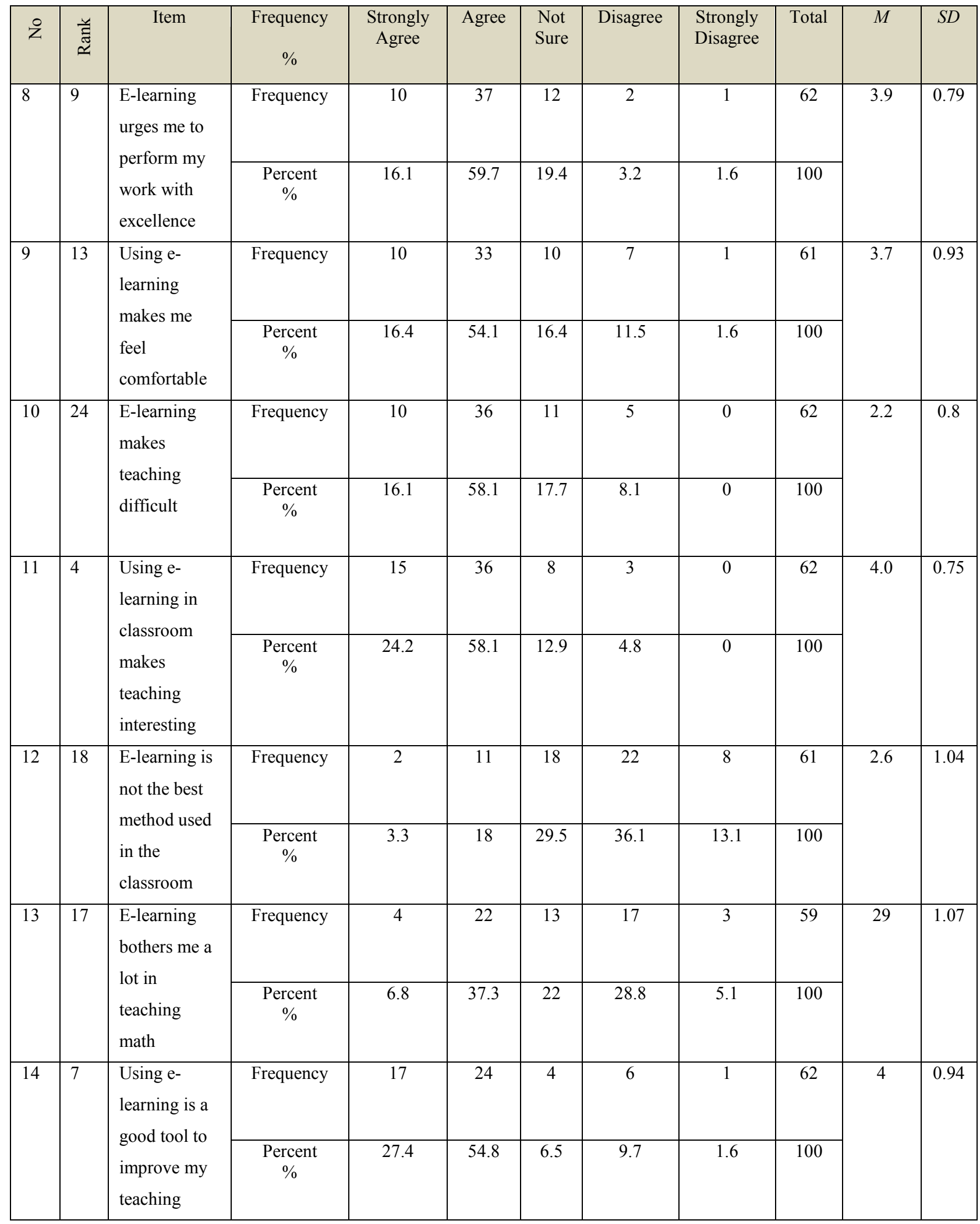


Table 7 (continued)

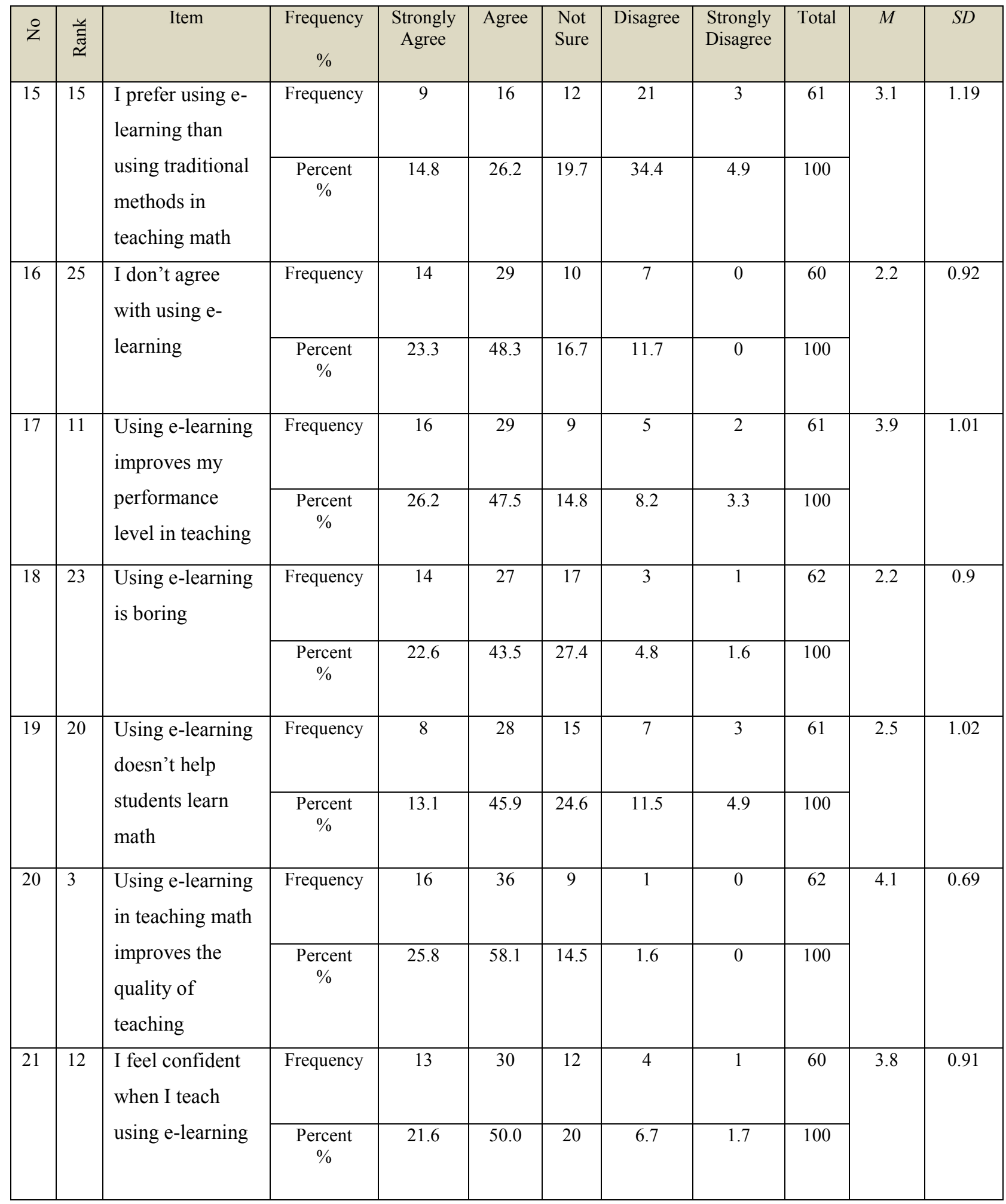


Table 7 (continued)

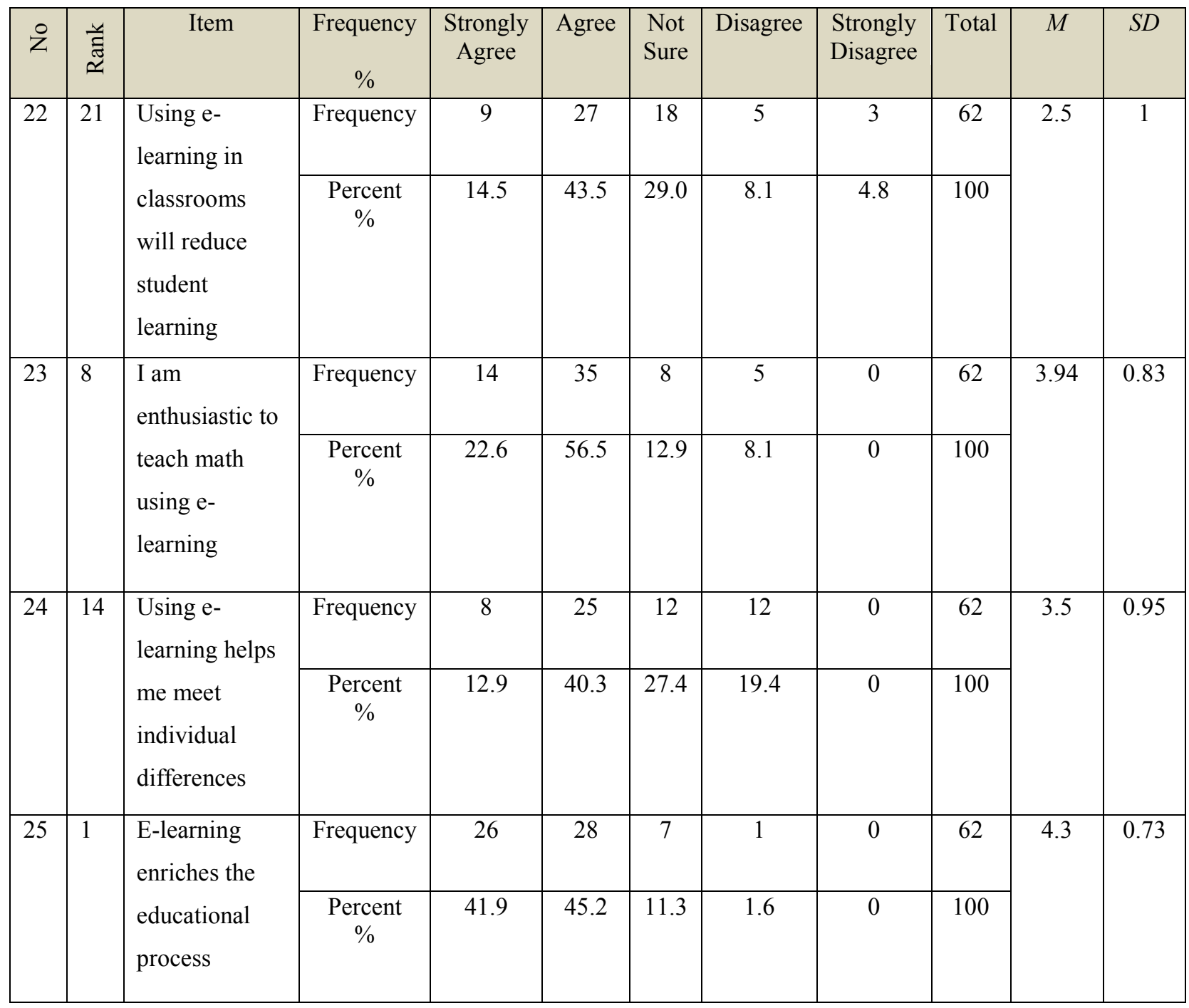


Table 8

Means, Standard Deviations, and t-test Values for Academic Degrees

\begin{tabular}{|c|c|c|c|c|c|c|c|c|}
\hline No. & Items & $\begin{array}{c}\text { Academic } \\
\text { Degree }\end{array}$ & $N$ & $M$ & $S D$ & $t$ & $p$ & Conclusion \\
\hline \multirow[t]{2}{*}{1} & \multirow{2}{*}{$\begin{array}{l}\text { I prefer using e-learning } \\
\text { to teach math }\end{array}$} & $\mathrm{BA}$ & 60 & 3.98 & 0.81 & \multirow[t]{2}{*}{-0.02} & \multirow[t]{2}{*}{.98} & \multirow{2}{*}{$\begin{array}{c}\text { No significan } \\
\text { differences }\end{array}$} \\
\hline & & MA & 1 & 4 & 0 & & & \\
\hline \multirow[t]{2}{*}{2} & \multirow{2}{*}{$\begin{array}{l}\text { I feel uncomfortable using } \\
\text { e-learning in teaching } \\
\text { math }\end{array}$} & $\overline{B A}$ & 57 & 2.35 & 1.15 & \multirow[t]{2}{*}{-0.56} & \multirow[t]{2}{*}{.58} & \multirow{2}{*}{$\begin{array}{c}\text { No significant } \\
\text { differences }\end{array}$} \\
\hline & & MA & 1 & 3 & 0 & & & \\
\hline \multirow[t]{2}{*}{3} & \multirow{2}{*}{$\begin{array}{l}\text { Using e-learning helps me } \\
\text { in teaching math }\end{array}$} & $\overline{B A}$ & 61 & 3.98 & 0.90 & \multirow[t]{2}{*}{1.08} & \multirow[t]{2}{*}{.29} & \multirow{2}{*}{$\begin{array}{c}\text { No significant } \\
\text { differences }\end{array}$} \\
\hline & & MA & 1 & 3 & 0 & & & \\
\hline \multirow[t]{2}{*}{4} & \multirow{2}{*}{$\begin{array}{l}\text { Using e-learning makes } \\
\text { teaching math more } \\
\text { effective }\end{array}$} & BA & 60 & 4.12 & 0.78 & \multirow[t]{2}{*}{1.41} & \multirow[t]{2}{*}{.16} & \multirow{2}{*}{$\begin{array}{c}\text { No significant } \\
\text { differences }\end{array}$} \\
\hline & & MA & 1 & 3 & 0 & & & \\
\hline \multirow[t]{2}{*}{5} & \multirow{2}{*}{$\begin{array}{l}\text { I never think of using e- } \\
\text { learning }\end{array}$} & $\overline{\mathrm{BA}}$ & 56 & 2.59 & 1.16 & \multirow[t]{2}{*}{0.51} & \multirow[t]{2}{*}{.62} & \multirow{2}{*}{$\begin{array}{c}\text { No significant } \\
\text { differences }\end{array}$} \\
\hline & & MA & 1 & 2 & 0 & & & \\
\hline \multirow[t]{2}{*}{6} & \multirow{2}{*}{$\begin{array}{l}\text { E-learning helps me } \\
\text { organizing my work }\end{array}$} & BA & 61 & 3.98 & 0.84 & \multirow[t]{2}{*}{-0.02} & \multirow[t]{2}{*}{.99} & \multirow{2}{*}{$\begin{array}{c}\text { No significant } \\
\text { differences }\end{array}$} \\
\hline & & MA & 1 & 4 & 0 & & & \\
\hline \multirow[t]{2}{*}{7} & \multirow{2}{*}{$\begin{array}{l}\text { I prefer to use the } \\
\text { chalkboard and textbooks } \\
\text { in teaching rather than } \\
\text { using e-learning }\end{array}$} & BA & 61 & 2.9 & 1.18 & -0.08 & .93 & No significant \\
\hline & & MA & 1 & 3 & 0 & & & differences \\
\hline 8 & E-learning urges me to & $\mathrm{BA}$ & 61 & 3.85 & 0.79 & -0.19 & .85 & No significant \\
\hline & $\begin{array}{l}\text { perform my work with } \\
\text { excellence }\end{array}$ & MA & 1 & 4 & 0 & & & differences \\
\hline 9 & E-learning makes me feel & $\mathrm{BA}$ & 61 & 3.72 & 0.94 & -0.3 & .77 & No significant \\
\hline & comfortable & MA & 1 & 4 & 0 & & & differences \\
\hline 10 & E-learning makes & $\mathrm{BA}$ & 60 & 3.72 & 0.81 & 0.22 & .83 & No significant \\
\hline & teaching difficult & MA & 1 & 4 & 0 & & & differences \\
\hline 11 & E-learning in classroom is & $\mathrm{BA}$ & 61 & 2.18 & 0.76 & 0.02 & .98 & No significant \\
\hline & interesting & MA & 1 & 2 & 0 & & & differences \\
\hline 12 & E-learning is not the best & BA & 61 & 4.02 & 1.04 & -0.37 & .72 & No significant \\
\hline & $\begin{array}{l}\text { method used in the } \\
\text { classroom }\end{array}$ & MA & 1 & 4 & 0 & & & differences \\
\hline
\end{tabular}


Table 8 (continued)

\begin{tabular}{|c|c|c|c|c|c|c|c|c|}
\hline No. & Items & $\begin{array}{l}\text { Academic } \\
\text { Degree }\end{array}$ & $N$ & $M$ & $S D$ & $t$ & $p$ & Conclusion \\
\hline \multirow[t]{2}{*}{13} & \multirow{2}{*}{$\begin{array}{l}\text { E-learning bothers me a } \\
\text { lot in teaching math. }\end{array}$} & $\mathrm{BA}$ & 60 & 2.62 & 1.07 & \multirow[t]{2}{*}{0.83} & \multirow[t]{2}{*}{.41} & \multirow{2}{*}{$\begin{array}{c}\text { No significant } \\
\text { differences }\end{array}$} \\
\hline & & $\mathrm{MA}$ & 1 & 3 & 0 & & & \\
\hline \multirow[t]{2}{*}{14} & \multirow{2}{*}{$\begin{array}{l}\text { E-learning is a good tool } \\
\text { that's improves my } \\
\text { teaching }\end{array}$} & BA & 58 & 2.90 & 0.95 & \multirow[t]{2}{*}{-0.03} & \multirow[t]{2}{*}{97} & \multirow{2}{*}{$\begin{array}{c}\text { No significant } \\
\text { differences }\end{array}$} \\
\hline & & MA & 1 & 2 & 0 & & & \\
\hline \multirow[t]{2}{*}{15} & \multirow{2}{*}{$\begin{array}{l}\text { I prefer e-learning than } \\
\text { traditional teaching } \\
\text { methods }\end{array}$} & $\mathrm{BA}$ & 61 & 3.97 & 1.19 & \multirow[t]{2}{*}{-0.75} & \multirow[t]{2}{*}{.46} & \multirow{2}{*}{$\begin{array}{c}\text { No significant } \\
\text { differences }\end{array}$} \\
\hline & & MA & 1 & 4 & 0 & & & \\
\hline \multirow[t]{2}{*}{16} & \multirow{2}{*}{$\begin{array}{l}\text { I don't agree with using e- } \\
\text { learning }\end{array}$} & BA & 60 & 3.1 & 0.93 & \multirow[t]{2}{*}{0.18} & \multirow[t]{2}{*}{.86} & \multirow{2}{*}{$\begin{array}{c}\text { No significant } \\
\text { differences }\end{array}$} \\
\hline & & MA & 1 & 4 & 0 & & & \\
\hline \multirow[t]{2}{*}{17} & \multirow{2}{*}{$\begin{array}{l}\text { Using e-learning } \\
\text { improves my performance } \\
\text { level in teaching }\end{array}$} & BA & 59 & 2.17 & 1.02 & \multirow[t]{2}{*}{-0.15} & \multirow[t]{2}{*}{.89} & \multirow{2}{*}{$\begin{array}{c}\text { No significant } \\
\text { differences }\end{array}$} \\
\hline & & MA & 1 & 2 & 0 & & & \\
\hline \multirow[t]{2}{*}{18} & \multirow[t]{2}{*}{ Using e-learning is boring } & $\mathrm{BA}$ & 60 & 3.85 & 0.91 & \multirow[t]{2}{*}{0.22} & \multirow[t]{2}{*}{.83} & \multirow{2}{*}{$\begin{array}{c}\text { No significant } \\
\text { differences }\end{array}$} \\
\hline & & $\mathrm{MA}$ & 1 & 4 & 0 & & & \\
\hline \multirow[t]{2}{*}{19} & Using e-learning doesn't & $\mathrm{BA}$ & 61 & 2.2 & 1.03 & 0.48 & .63 & No significant \\
\hline & & MA & 1 & 2 & 0 & & & differences \\
\hline 20 & E-learning in teaching & $\mathrm{BA}$ & 60 & 2.5 & 0.69 & 0.12 & .63 & No significant \\
\hline & $\begin{array}{l}\text { math improves the quality } \\
\text { of teaching }\end{array}$ & MA & 1 & 2 & 0 & & & differences \\
\hline 21 & I feel confident when I & $\mathrm{BA}$ & 61 & 4.08 & 0.91 & -0.18 & .86 & No significant \\
\hline & teach using e-learning & $\mathrm{MA}$ & 1 & 4 & 0 & & & differences \\
\hline 22 & Using e-learning in & $\mathrm{BA}$ & 59 & 3.83 & 1.01 & 0.45 & .65 & No significant \\
\hline & $\begin{array}{l}\text { classrooms will reduce } \\
\text { student learning }\end{array}$ & MA & 1 & 4 & 0 & & & differences \\
\hline 23 & I am enthusiastic to teach & $\mathrm{BA}$ & 61 & 2.46 & 0.96 & -0.56 & .58 & No significant \\
\hline & math using e-learning & MA & 1 & 2 & 0 & & & differences \\
\hline 24 & E-learning helps me to & $\mathrm{BA}$ & 61 & 3.46 & 0.96 & -0.56 & .58 & No significant \\
\hline & $\begin{array}{l}\text { observe individual } \\
\text { differences }\end{array}$ & MA & 1 & 4 & 0 & & & differences \\
\hline 25 & E-learning enriches the & BA & 61 & 4.26 & 0.73 & -1.01 & .32 & No significant \\
\hline & educational process & MA & 1 & 5 & 0 & & & differences \\
\hline
\end{tabular}


Table 9

Teachers' Response Variance for Years of Teaching Experience

\begin{tabular}{|c|c|c|c|c|c|c|c|c|}
\hline No & Items & Variance & $d f$ & $S S$ & $M S$ & $F$ & $p$ & Conclusion \\
\hline \multirow[t]{2}{*}{1} & \multirow{2}{*}{$\begin{array}{l}\text { I prefer using e- } \\
\text { learning to teach math }\end{array}$} & Inter & 3 & 0.52 & 0.17 & \multirow[t]{2}{*}{0.26} & \multirow[t]{2}{*}{.86} & \multirow{2}{*}{$\begin{array}{c}\text { No significant } \\
\text { differences }\end{array}$} \\
\hline & & Intra & 57 & 38.47 & $\begin{array}{l}0.68 \\
\end{array}$ & & & \\
\hline \multirow[t]{2}{*}{2} & \multirow{2}{*}{$\begin{array}{l}\text { I feel uncomfortable } \\
\text { using e-learning in } \\
\text { teaching math }\end{array}$} & Inter & 3 & 3.59 & 1.2 & \multirow[t]{2}{*}{0.90} & \multirow[t]{2}{*}{.45} & \multirow{2}{*}{$\begin{array}{c}\text { No significant } \\
\text { differences }\end{array}$} \\
\hline & & Intra & 54 & 71.81 & 1.33 & & & \\
\hline \multirow[t]{2}{*}{3} & \multirow{2}{*}{$\begin{array}{l}\text { Using e-learning helps } \\
\text { me in teaching math }\end{array}$} & Inter & 3 & 2.37 & 0.79 & \multirow[t]{2}{*}{0.96} & \multirow[t]{2}{*}{.42} & \multirow{2}{*}{$\begin{array}{l}\text { No significant } \\
\text { differences }\end{array}$} \\
\hline & & Intra & 58 & 47.57 & 0.82 & & & \\
\hline \multirow[t]{2}{*}{4} & \multirow{2}{*}{$\begin{array}{l}\text { Using e-learning } \\
\text { makes teaching math } \\
\text { more effective }\end{array}$} & Inter & 3 & 2.11 & 0.70 & \multirow[t]{2}{*}{1.14} & \multirow[t]{2}{*}{.34} & \multirow{2}{*}{$\begin{array}{c}\text { No significant } \\
\text { differences }\end{array}$} \\
\hline & & Intra & 57 & 35.3 & 0.62 & & & \\
\hline \multirow[t]{2}{*}{5} & \multirow{2}{*}{$\begin{array}{l}\text { I never think of using } \\
\text { e-learning }\end{array}$} & Inter & 3 & 1.95 & 0.65 & \multirow[t]{2}{*}{0.48} & \multirow[t]{2}{*}{.70} & \multirow{2}{*}{$\begin{array}{c}\text { No significant } \\
\text { differences }\end{array}$} \\
\hline & & Intra & 53 & 71.94 & 1.36 & & & \\
\hline \multirow[t]{2}{*}{6} & \multirow{2}{*}{$\begin{array}{l}\text { E-learning helps me } \\
\text { organizing my work }\end{array}$} & Inter & 3 & 1.68 & 0.56 & \multirow[t]{2}{*}{0.79} & \multirow[t]{2}{*}{.51} & \multirow{2}{*}{$\begin{array}{l}\text { No significant } \\
\text { differences }\end{array}$} \\
\hline & & Intra & 58 & 41.3 & 0.71 & & & \\
\hline \multirow[t]{2}{*}{7} & \multirow{2}{*}{$\begin{array}{l}\text { I prefer to use the } \\
\text { chalkboard and } \\
\text { textbooks in teaching } \\
\text { rather than using e- } \\
\text { learning }\end{array}$} & Inter & 3 & 6.32 & 2.11 & \multirow[t]{2}{*}{1.59} & .20 & No significant \\
\hline & & Intra & 58 & 77.1 & 1.33 & & & differences \\
\hline 8 & E-learning urges me to & Inter & 3 & 1.26 & 0.42 & 0.67 & .57 & No significant \\
\hline & $\begin{array}{l}\text { perform my work with } \\
\text { excellence }\end{array}$ & Intra & 58 & 36.46 & 0.62 & & & differences \\
\hline 9 & E-learning makes me & Inter & 3 & 2.06 & 0.69 & 0.78 & .51 & No significant \\
\hline & feel comfortable & Intra & 57 & 50.2 & 0.88 & & & differences \\
\hline 10 & E-learning makes & Inter & 3 & 2.99 & 1 & 1.60 & .20 & No significant \\
\hline & teaching difficult & Intra & 58 & 36.06 & 0.62 & & & differences \\
\hline 11 & E-learning in & Inter & 3 & 0.4 & 0.13 & 0.22 & .88 & No significant \\
\hline & $\begin{array}{l}\text { classroom is } \\
\text { interesting }\end{array}$ & Intra & 58 & 34.59 & 0.6 & & & differences \\
\hline
\end{tabular}


Table 9 (continued)

\begin{tabular}{|c|c|c|c|c|c|c|c|c|}
\hline No & Items & Variance & $d f$ & $S S$ & $M S$ & $F$ & $p$ & Conclusion \\
\hline \multirow[t]{2}{*}{12} & \multirow{2}{*}{$\begin{array}{l}\text { E-learning is not the } \\
\text { best method used in } \\
\text { the classroom }\end{array}$} & Inter & 3 & 3.5 & 1.17 & \multirow[t]{2}{*}{1.09} & \multirow[t]{2}{*}{.36} & \multirow{2}{*}{$\begin{array}{c}\text { No significant } \\
\text { differences }\end{array}$} \\
\hline & & Intra & 57 & 60.83 & 1.07 & & & \\
\hline \multirow[t]{2}{*}{13} & \multirow{2}{*}{$\begin{array}{l}\text { E-learning bothers me } \\
\text { a lot in teaching math. }\end{array}$} & Inter & 3 & 1.55 & 0.52 & \multirow[t]{2}{*}{0.44} & \multirow[t]{2}{*}{.73} & \multirow{2}{*}{$\begin{array}{c}\text { No significant } \\
\text { differences }\end{array}$} \\
\hline & & Intra & 55 & 64.62 & 1.18 & & & \\
\hline \multirow[t]{2}{*}{14} & \multirow{2}{*}{$\begin{array}{l}\text { E-learning is a good } \\
\text { tool that's improves } \\
\text { my teaching }\end{array}$} & Inter & 3 & 1.2 & 0.40 & \multirow[t]{2}{*}{0.44} & \multirow[t]{2}{*}{.73} & \multirow{2}{*}{$\begin{array}{c}\text { No significant } \\
\text { differences }\end{array}$} \\
\hline & & Intra & 58 & 52.73 & 0.91 & & & \\
\hline \multirow[t]{2}{*}{15} & \multirow{2}{*}{$\begin{array}{l}\text { I prefer e-learning than } \\
\text { traditional teaching } \\
\text { methods }\end{array}$} & Inter & 3 & 0.28 & 0.09 & \multirow[t]{2}{*}{0.06} & \multirow[t]{2}{*}{.98} & \multirow{2}{*}{$\begin{array}{c}\text { No significant } \\
\text { differences }\end{array}$} \\
\hline & & Intra & 57 & 83.92 & 1.47 & & & \\
\hline \multirow[t]{2}{*}{16} & \multirow{2}{*}{$\begin{array}{l}\text { I don't agree with } \\
\text { using e-learning }\end{array}$} & Inter & 3 & 2.3 & 0.77 & \multirow[t]{2}{*}{0.89} & \multirow[t]{2}{*}{.45} & \multirow{2}{*}{$\begin{array}{c}\text { No significant } \\
\text { differences }\end{array}$} \\
\hline & & Intra & 56 & 48.04 & 0.86 & & & \\
\hline \multirow[t]{2}{*}{17} & \multirow{2}{*}{$\begin{array}{l}\text { Using e-learning } \\
\text { improves my } \\
\text { performance level in } \\
\text { teaching }\end{array}$} & Inter & 3 & 2.82 & 0.94 & \multirow[t]{2}{*}{0.91} & \multirow[t]{2}{*}{.44} & \multirow{2}{*}{$\begin{array}{c}\text { No significant } \\
\text { differences }\end{array}$} \\
\hline & & Intra & 57 & 58.86 & 1.03 & & & \\
\hline \multirow[t]{2}{*}{18} & \multirow{2}{*}{$\begin{array}{l}\text { Using e-learning is } \\
\text { boring }\end{array}$} & Inter & 3 & 3.47 & 1.16 & \multirow[t]{2}{*}{1.45} & .23 & No significant \\
\hline & & Intra & 58 & 46.2 & 0.8 & & & differences \\
\hline 19 & Using e-learning & Inter & 3 & 3.78 & 1.26 & 1.21 & .32 & No significant \\
\hline & $\begin{array}{l}\text { doesn't help students } \\
\text { learn math. }\end{array}$ & Intra & 57 & 59.47 & 1.04 & & & differences \\
\hline 20 & E-learning in teaching & Inter & 3 & 0.67 & 0.22 & 0.47 & .71 & No significant \\
\hline & $\begin{array}{l}\text { math improves the } \\
\text { quality of teaching }\end{array}$ & Intra & 58 & 27.93 & 0.48 & & & differences \\
\hline 21 & I feel confident when I & Inter & 3 & 2.31 & 0.22 & 0.94 & .43 & No significant \\
\hline & teach using e-learning & Intra & 56 & 46.02 & 0.48 & & & differences \\
\hline 22 & Using e-learning in & Inter & 3 & 0.91 & 0.30 & 0.29 & .83 & No significant \\
\hline & $\begin{array}{l}\text { classrooms will reduce } \\
\text { student learning }\end{array}$ & Intra & 58 & 60.45 & 1.04 & & & differences \\
\hline
\end{tabular}


Table 9 (continued)

\begin{tabular}{|c|c|c|c|c|c|c|c|c|}
\hline No & Items & Variance & $d f$ & $S S$ & $M S$ & $F$ & $p$ & Conclusion \\
\hline \multirow[t]{2}{*}{23} & \multirow{2}{*}{$\begin{array}{l}\text { I am enthusiastic to } \\
\text { teach math using e- } \\
\text { learning }\end{array}$} & Inter & 3 & 0.37 & 0.12 & \multirow[t]{2}{*}{0.13} & \multirow[t]{2}{*}{.91} & \multirow{2}{*}{$\begin{array}{c}\text { No significant } \\
\text { differences }\end{array}$} \\
\hline & & Intra & 58 & 41.37 & 0.71 & & & \\
\hline \multirow[t]{2}{*}{24} & \multirow{2}{*}{$\begin{array}{l}\text { E-learning helps me to } \\
\text { observe individual } \\
\text { differences }\end{array}$} & Inter & 3 & 1.35 & 0.45 & \multirow[t]{2}{*}{0.48} & \multirow[t]{2}{*}{.70} & \multirow{2}{*}{$\begin{array}{c}\text { No significant } \\
\text { differences }\end{array}$} \\
\hline & & Intra & 58 & 54.09 & 0.93 & & & \\
\hline \multirow[t]{2}{*}{25} & \multirow{2}{*}{$\begin{array}{l}\text { E-learning enriches } \\
\text { the educational } \\
\text { process }\end{array}$} & Inter & 3 & 1.39 & 0.46 & \multirow[t]{2}{*}{0.87} & \multirow[t]{2}{*}{.46} & \multirow{2}{*}{$\begin{array}{c}\text { No significant } \\
\text { differences }\end{array}$} \\
\hline & & Intra & 58 & 30.95 & 0.53 & & & \\
\hline
\end{tabular}


Table 10

Means, Standard Deviation, and t-test Values for Computer Training Courses

\begin{tabular}{|c|c|c|c|c|c|c|c|c|}
\hline No & Items & Variance & $N$ & $M$ & $S D$ & $t$ & $p$ & Conclusion \\
\hline \multirow[t]{2}{*}{1} & \multirow{2}{*}{$\begin{array}{l}\text { I prefer using e-learning to } \\
\text { teach math }\end{array}$} & Trained & 29 & 3.86 & 0.95 & \multirow[t]{2}{*}{-0.96} & \multirow[t]{2}{*}{.34} & \multirow{2}{*}{$\begin{array}{c}\text { No significant } \\
\text { differences }\end{array}$} \\
\hline & & $\begin{array}{c}\text { Not } \\
\text { Trained }\end{array}$ & 28 & 4.07 & 0.66 & & & \\
\hline \multirow[t]{2}{*}{2} & \multirow{2}{*}{$\begin{array}{l}\text { I feel uncomfortable using } \\
\text { e-learning in teaching math }\end{array}$} & Trained & 28 & 3.86 & 0.95 & \multirow[t]{2}{*}{1.11} & \multirow[t]{2}{*}{.27} & \multirow{2}{*}{$\begin{array}{c}\text { No significant } \\
\text { differences }\end{array}$} \\
\hline & & $\begin{array}{c}\text { Not } \\
\text { Trained }\end{array}$ & 27 & 2.22 & 1.07 & & & \\
\hline \multirow[t]{2}{*}{3} & \multirow{2}{*}{$\begin{array}{l}\text { Using e-learning helps me } \\
\text { in teaching math }\end{array}$} & Trained & 29 & 3.97 & 0.98 & \multirow[t]{2}{*}{0.30} & \multirow[t]{2}{*}{.77} & \multirow{2}{*}{$\begin{array}{c}\text { No significant } \\
\text { differences }\end{array}$} \\
\hline & & $\begin{array}{c}\text { Not } \\
\text { Trained }\end{array}$ & 28 & 3.89 & 0.87 & & & \\
\hline \multirow[t]{2}{*}{4} & \multirow{2}{*}{$\begin{array}{l}\text { Using e-learning makes } \\
\text { teaching math more } \\
\text { effective }\end{array}$} & Trained & 29 & 4.14 & 0.88 & \multirow[t]{2}{*}{0.47} & \multirow[t]{2}{*}{.64} & \multirow{2}{*}{$\begin{array}{c}\text { No significant } \\
\text { differences }\end{array}$} \\
\hline & & $\begin{array}{c}\text { Not } \\
\text { Trained }\end{array}$ & 28 & 4.04 & 0.74 & & & \\
\hline \multirow[t]{2}{*}{5} & \multirow{2}{*}{$\begin{array}{l}\text { I never think of using e- } \\
\text { learning }\end{array}$} & Trained & 27 & 2.70 & 1.24 & \multirow[t]{2}{*}{0.39} & \multirow[t]{2}{*}{.70} & \multirow{2}{*}{$\begin{array}{c}\text { No significant } \\
\text { differences }\end{array}$} \\
\hline & & $\begin{array}{c}\text { Not } \\
\text { Trained }\end{array}$ & 26 & 2.58 & 1.10 & & & \\
\hline \multirow[t]{2}{*}{6} & \multirow{2}{*}{$\begin{array}{l}\text { E-learning helps me } \\
\text { organizing my work }\end{array}$} & Trained & 29 & 3.83 & 1.00 & \multirow[t]{2}{*}{0.10} & \multirow[t]{2}{*}{.29} & \multirow{2}{*}{$\begin{array}{c}\text { No significant } \\
\text { differences }\end{array}$} \\
\hline & & $\begin{array}{c}\text { Not } \\
\text { Trained }\end{array}$ & 28 & 4.07 & 0.66 & & & \\
\hline \multirow[t]{2}{*}{7} & \multirow{2}{*}{$\begin{array}{l}\text { I prefer to use the } \\
\text { chalkboard and textbooks in } \\
\text { teaching rather than using } \\
\text { e-learning }\end{array}$} & Trained & 28 & 2.79 & 1.20 & \multirow[t]{2}{*}{-0.65} & \multirow[t]{2}{*}{.52} & \multirow{2}{*}{$\begin{array}{c}\text { No significant } \\
\text { differences }\end{array}$} \\
\hline & & $\begin{array}{c}\text { Not } \\
\text { Trained }\end{array}$ & 28 & 3.00 & 1.19 & & & \\
\hline 8 & E-learning urges me to & Trained & 29 & 3.72 & 0.92 & -0.90 & .37 & No significant \\
\hline & $\begin{array}{l}\text { perform my work with } \\
\text { excellence }\end{array}$ & $\begin{array}{c}\text { Not } \\
\text { Trained }\end{array}$ & 28 & 3.96 & 0.64 & & & differences \\
\hline 9 & E-learning makes me feel & Trained & 29 & 3.62 & 1.05 & 1.27 & .21 & No significant \\
\hline & comfortable & $\begin{array}{c}\text { Not } \\
\text { Trained }\end{array}$ & 27 & 3.85 & 0.86 & & & differences \\
\hline
\end{tabular}


Table 10 (continued)

\begin{tabular}{|c|c|c|c|c|c|c|c|c|}
\hline No & Items & Variance & $N$ & $M$ & $S D$ & $t$ & $p$ & Conclusion \\
\hline \multirow[t]{2}{*}{10} & \multirow{2}{*}{$\begin{array}{l}\text { E-learning makes teaching } \\
\text { difficult }\end{array}$} & Trained & 29 & 2.34 & 0.81 & \multirow[t]{2}{*}{-1.95} & \multirow[t]{2}{*}{.06} & \multirow{2}{*}{$\begin{array}{c}\text { No significant } \\
\text { differences }\end{array}$} \\
\hline & & $\begin{array}{c}\text { Not } \\
\text { Trained }\end{array}$ & 28 & 2.07 & 0.81 & & & \\
\hline \multirow[t]{2}{*}{11} & \multirow{2}{*}{$\begin{array}{l}\text { E-learning in classroom is } \\
\text { interesting }\end{array}$} & Trained & 29 & 3.83 & 0.89 & \multirow[t]{2}{*}{-1.95} & \multirow[t]{2}{*}{.06} & \multirow{2}{*}{$\begin{array}{c}\text { No significant } \\
\text { differences }\end{array}$} \\
\hline & & $\begin{array}{c}\text { Not } \\
\text { Trained }\end{array}$ & 28 & 4.21 & 0.57 & & & \\
\hline \multirow[t]{2}{*}{12} & \multirow{2}{*}{$\begin{array}{l}\text { E-learning is not the best } \\
\text { method used in the } \\
\text { classroom }\end{array}$} & Trained & 28 & 2.68 & 1.09 & \multirow[t]{2}{*}{0.38} & \multirow[t]{2}{*}{.73} & \multirow{2}{*}{$\begin{array}{c}\text { No significant } \\
\text { differences }\end{array}$} \\
\hline & & $\begin{array}{c}\text { Not } \\
\text { Trained }\end{array}$ & 28 & 2.57 & 1.03 & & & \\
\hline \multirow[t]{2}{*}{13} & \multirow{2}{*}{$\begin{array}{l}\text { E-learning bothers me a lot } \\
\text { in teaching math. }\end{array}$} & Trained & 28 & 3.04 & 1.20 & \multirow[t]{2}{*}{1.15} & \multirow[t]{2}{*}{.26} & \multirow{2}{*}{$\begin{array}{c}\text { No significant } \\
\text { differences }\end{array}$} \\
\hline & & $\begin{array}{c}\text { Not } \\
\text { Trained }\end{array}$ & 26 & 2.69 & 0.97 & & & \\
\hline \multirow[t]{2}{*}{14} & \multirow{2}{*}{$\begin{array}{l}\text { E-learning is a good tool } \\
\text { that's improves my teaching }\end{array}$} & Trained & 29 & 3.37 & 1.01 & \multirow[t]{2}{*}{-0.96} & \multirow[t]{2}{*}{.34} & \multirow{2}{*}{$\begin{array}{c}\text { No significant } \\
\text { differences }\end{array}$} \\
\hline & & $\begin{array}{c}\text { Not } \\
\text { Trained }\end{array}$ & 28 & 4.04 & 0.88 & & & \\
\hline \multirow[t]{2}{*}{15} & \multirow{2}{*}{$\begin{array}{l}\text { I prefer e-learning than } \\
\text { traditional teaching } \\
\text { methods }\end{array}$} & Trained & 28 & 3.00 & 1.09 & \multirow[t]{2}{*}{-1.12} & \multirow[t]{2}{*}{.27} & \multirow{2}{*}{$\begin{array}{c}\text { No significant } \\
\text { differences }\end{array}$} \\
\hline & & $\begin{array}{c}\text { Not } \\
\text { Trained }\end{array}$ & 28 & 3.36 & 1.28 & & & \\
\hline \multirow[t]{2}{*}{16} & \multirow{2}{*}{$\begin{array}{l}\text { I don't agree with using e- } \\
\text { learning }\end{array}$} & Trained & 29 & 2.28 & 1.00 & \multirow[t]{2}{*}{0.65} & \multirow[t]{2}{*}{.52} & No significant \\
\hline & & $\begin{array}{c}\text { Not } \\
\text { Trained }\end{array}$ & 27 & 2.11 & 0.89 & & & differences \\
\hline 17 & Using e-learning improves & Trained & 29 & 3.72 & 1.10 & -0.98 & .33 & No significant \\
\hline & $\begin{array}{l}\text { my performance level in } \\
\text { teaching }\end{array}$ & $\begin{array}{c}\text { Not } \\
\text { Trained }\end{array}$ & 27 & 4.00 & 1.00 & & & differences \\
\hline 18 & Using e-learning is boring & Trained & 29 & 2.31 & 1.07 & 0.83 & .43 & No significant \\
\hline & & $\begin{array}{c}\text { Not } \\
\text { Trained }\end{array}$ & 28 & 2.11 & 0.73 & & & differences \\
\hline 19 & Using e-learning doesn't & Trained & 28 & 2.43 & 1.13 & -0.50 & .62 & No significant \\
\hline & help students learn math. & $\begin{array}{c}\text { Not } \\
\text { Trained }\end{array}$ & 28 & 2.57 & 0.99 & & & differences \\
\hline
\end{tabular}


Table 10 (continued)

\begin{tabular}{|c|c|c|c|c|c|c|c|c|}
\hline No & Items & Variance & $N$ & $M$ & $S D$ & $t$ & $p$ & Conclusion \\
\hline \multirow[t]{2}{*}{20} & \multirow{2}{*}{$\begin{array}{l}\text { E-learning in teaching math } \\
\text { improves the quality of } \\
\text { teaching }\end{array}$} & Trained & 29 & 3.86 & 0.69 & \multirow[t]{2}{*}{-2.36} & \multirow[t]{2}{*}{.02} & \multirow{2}{*}{$\begin{array}{l}\text { There were } \\
\text { significant } \\
\text { differences }\end{array}$} \\
\hline & & $\begin{array}{c}\text { Not } \\
\text { Trained }\end{array}$ & 28 & 4.29 & 0.66 & & & \\
\hline \multirow[t]{2}{*}{21} & \multirow{2}{*}{$\begin{array}{l}\text { I feel confident when I } \\
\text { teach using e-learning }\end{array}$} & Trained & 29 & 3.66 & 1.01 & \multirow[t]{2}{*}{-1.25} & \multirow[t]{2}{*}{.22} & \multirow{2}{*}{$\begin{array}{c}\text { No significant } \\
\text { differences }\end{array}$} \\
\hline & & $\begin{array}{c}\text { Not } \\
\text { Trained }\end{array}$ & 27 & 3.96 & 0.81 & & & \\
\hline \multirow[t]{2}{*}{22} & \multirow{2}{*}{$\begin{array}{l}\text { Using e-learning in } \\
\text { classrooms will reduce } \\
\text { student learning }\end{array}$} & Trained & 29 & 2.59 & 1.09 & \multirow[t]{2}{*}{0.98} & \multirow[t]{2}{*}{.33} & \multirow{2}{*}{$\begin{array}{c}\text { No significant } \\
\text { differences }\end{array}$} \\
\hline & & $\begin{array}{c}\text { Not } \\
\text { Trained }\end{array}$ & 28 & 2.32 & 0.94 & & & \\
\hline \multirow[t]{2}{*}{23} & \multirow{2}{*}{$\begin{array}{l}\text { I am enthusiastic to teach } \\
\text { math using e-learning }\end{array}$} & Trained & 29 & 3.83 & 0.93 & \multirow[t]{2}{*}{-0.91} & \multirow[t]{2}{*}{.36} & \multirow{2}{*}{$\begin{array}{c}\text { No significant } \\
\text { differences }\end{array}$} \\
\hline & & $\begin{array}{c}\text { Not } \\
\text { Trained }\end{array}$ & 29 & 3.23 & 1.00 & & & \\
\hline \multirow[t]{2}{*}{24} & \multirow{2}{*}{$\begin{array}{l}\text { E-learning helps me to } \\
\text { observe individual } \\
\text { differences }\end{array}$} & Trained & 29 & 3.28 & 1.00 & \multirow[t]{2}{*}{-1.33} & \multirow[t]{2}{*}{.19} & \multirow{2}{*}{$\begin{array}{c}\text { No significant } \\
\text { differences }\end{array}$} \\
\hline & & $\begin{array}{c}\text { Not } \\
\text { Trained }\end{array}$ & 28 & 3.61 & 0.88 & & & \\
\hline \multirow[t]{2}{*}{25} & \multirow{2}{*}{$\begin{array}{l}\text { E-learning enriches the } \\
\text { educational process }\end{array}$} & Trained & 29 & 4.17 & 0.71 & \multirow[t]{2}{*}{-0.76} & \multirow[t]{2}{*}{.45 } & \multirow{2}{*}{$\begin{array}{c}\text { No significant } \\
\text { differences }\end{array}$} \\
\hline & & $\begin{array}{c}\text { Not } \\
\text { Trained }\end{array}$ & 28 & 4.32 & 0.77 & & & \\
\hline
\end{tabular}

